\title{
Federal Interference with State and Tribal Sports Betting Regulations Will Not Work: Where the Sports Wagering Integrity Act of 2018 Went Wrong and How Federal Legislation Might Be Effective
}

\author{
Becky Harris*
}

\section{Background}

On Monday, May 14, 2018, the Supreme Court of the United States struck a fatal blow to the federal Professional and Amateur Sports Protection Act (PASPA) when it determined PASPA violated the Tenth Amendment of the United States Constitution. ${ }^{1}$ Prior to the PASPA repeal, Nevada had been the only state in the United States (US) authorized to offer a full complement of legal sports betting options. ${ }^{2}$ Because Nevada's race books and sports pools have had the ability to offer wagers on sports since $1947,{ }^{3}$ those legal sports betting operations were exempted when PASPA was passed by Congress in $1992 .{ }^{4}$

\footnotetext{
${ }^{1}$ The 10th Amendment to the United States Constitution states, "The powers not delegated to the United States by the Constitution, nor prohibited by it to the States, are reserved to the States respectively, or to the people." U.S. Const. Amend. X. In Murphy v. National Collegiate Athletic Association, the Supreme Court held that PASPA's provision preventing states from authorizing legal sports betting in their jurisdictions violated the anti-commandeering doctrine in the 10th Amendment., Murphy v. Nat'l Collegiate Athletic Ass'n, 584 U.S._, 138 S. Ct. 1461 (2018).

${ }^{2}$ Sean Gregory, The Risks and Rewards of the Supreme Court's Sports Gambling Decision, Time, (May 17, 2018), https://time.com/5280442/supreme-court-sports-betting-repeal/, accessed April 1, 2020.

${ }^{3}$ Richard N. Velotta, Legalize Sports Wagering Elsewhere Might Not Affect Nevada Much, L.V. Sun (Jan. 6, 2013).

${ }^{4}$ Kate Main, The Constitutionality of PASPA, St. Louis University L. J., https://www.slu.edu/law/ law-journal/online/2017-18/the-constitutionality-of-paspa.php, accessed March 02, 2020.

* Becky Harris is a Distinguished Fellow in Gaming \& Leadership at the International Gaming Institute at the University of Nevada, Las Vegas. She collaborates with regulators, academicians, and other stakeholders on a host of gaming and leadership related issues and projects. She is also an adjunct law professor at the Boyd School of Law at UNLV, where she teaches Gaming Law and Policy. A former Nevada state senator, she had the privilege of being named the first female chair of the Nevada Gaming Control Board. Email: becky.harris@unlv.edu
} 
Having anticipated repeal as a possible outcome, four states ${ }^{5}$ passed laws making sports betting legal in case the Supreme Court ruled in New Jersey's favor, and one state pre-emptively legalized sports betting through a ballot measure. ${ }^{6}$ With barriers removed by the PASPA repeal, state gambling regulators were able to grant licenses and adopt regulations. State legislatures were also able to legalize sports wagering during their upcoming legislative sessions. And they did!

On May 22, 2018, gaming regulators from four states issued a statement expressing confidence in the ability of state and tribal jurisdictions to regulate legalized sports betting. ${ }^{7}$ They affirmed, "Sports betting in Nevada has already been regulated with integrity and success, and gaming jurisdictions across the United States, including tribal jurisdictions, have demonstrated their ability to oversee gaming of all sorts while adhering to the highest standards." ${ }^{8}$ Moreover, "states and tribal gaming regulatory agencies have the capacity, resources, and ability to oversee the regulation of legalized sports betting." most mature gaming jurisdiction in the US, "Nevada having both the depth and experience with legalized, regulated sports wagering, serves as a leader to help guide us and other jurisdictions through this historical time." 10

Delaware became the second state in the nation to offer legal Nevada-style sports wagering, ${ }^{11}$ or single-game sports wagering, on June 5, 2018, when less than a month after PASPA's demise, its first sports bets were placed. ${ }^{12}$ New Jersey

\footnotetext{
${ }^{5}$ Delaware, Mississippi, Pennsylvania and West Virginia. Matthew Kredell, One year after PASPA Repeal, Sports Betting Legislation Appears In More than 75\% of US, LEGAL SPORTS ReP. (May 14, 2019), https://www.legalsportsreport.com/32440/sports-betting-legislation-after-paspa/, accessed April 21, 2020.

${ }^{6}$ Id. Arkansas voters legalized sports betting by supporting Issue No. 4 (a constitutional amendment) offered on the 2018 slate of ballot measures, Arkansas Secretary of State, Notice for Constitutional Amendment Proposed by Petition of the People, Issue No. 4, Section 1, § 2(c), 2018, https://www.sos.arkansas.gov/uploads/elections/Issue 4 for_Website.pdf, accessed April 21, 2020.
}

${ }^{7}$ The four states included Nevada, Massachusetts, Louisiana, and Michigan. On July 23, 2018, two more states, New Jersey and Mississippi, signed on to the original regulator statement. State Gambling Regulators Equipped and Ready to Take Charge on Legal Sports betting Industry, (May 22,2018 ) (on file with author), p. 1.

${ }^{8} I d$.

${ }^{9}$ Id.

${ }^{10} \mathrm{Id}$.

${ }^{11}$ Robert Mann, The Marriage of Sports Betting, Analytics and Novice Bettors, Sports Handle (Mar. 27, 2018), https://sportshandle.com/sports-betting-in-us-data-analytics-industry/, accessed April, 14, 2020.

${ }_{12}$ AFP, First sports bets placed in Delaware after ban lifted, YAHоo! News (June 5, 2018), https:// news.yahoo.com/first-sports-bets-placed-delaware-ban-lifted-224409080--spt.html, accessed March 2, 2020. 
sports betting went live just over a week later (one month to the day after the PASPA repeal). ${ }^{13}$ On July 23 , two more state regulators signed on to the gaming regulator statement issued in May. ${ }^{14}$ One of the additional signers, Mississippi, allowed sports enthusiasts to place their first sports bets just over a week later on August 1, 2018. ${ }^{15}$

The speed with which states began to roll out legal sports wagering was almost dizzying so it is not really much of a surprise that legalized sports wagering caught the attention of federal lawmakers, Senators Charles Schumer and Orrin Hatch. Though Hatch, one of four original authors of PASPA, announced plans to introduce a measure establishing new standards for sports betting the day after the Supreme Court struck down PASPA, ${ }^{16}$ Schumer got there first.

On August 29, 2018, ${ }^{17}$ Schumer released his vision of a federal sports betting framework, which included:

- a national prohibition for the placement of sports wagers by anyone under the age of 21 ;

- an obligation for sports book operators, leagues, and state regulators to share information, notify each other of suspicious activities, and coordinate enforcement actions;

- a requirement that sports book operators use official league data to determine outcomes;

- agreements between gaming regulators and leagues on acceptable wagers; and

${ }_{13}$ A.P., New Jersey Gov. Murphy places state's first legal sports bets after landmark Supreme Court ruling, NBC News (June 14, 2018), https://www.nbcnews.com/politics/supreme-court/newjersey-gov-murphy-places-state-s-first-legal-sports-n883121, accessed March 2, 2020.

${ }^{14}$ Media Statement on Behalf of U.S. State Gaming Regulators Forum, Two More States Add Support To The Statement Previously Issued By State Gambling Regulators, (July 23, 2018) (on file with author), p. 1.

${ }^{15}$ Steven Gagliano, First legal sports bet placed in Mississippi, NewMS.fm, Aug. 1, 2018, https:// newsms.fm/first-legal-sports-bet-placed-in-mississippi/, accessed March 2, 2020.

${ }^{16}$ Martin Derbyshire, PASPA Author Orrin Hatch To Introduce Federal Sports Betting Bill, PLAY USA (May 15, 2018), https://www.playusa.com/hatch-sports-betting-federal-bill/, accessed March 2, 2020.

${ }^{17}$ In Wake of Supreme Court Decision Freeing States to Legalize Sports Betting, Schumer Proposes Desperately-Needed Federal Framework to Protect Consumers and Integrity of Sports As State Legislatures Begin Lawmaking Efforts (Aug. 29, 2018), https://www.democrats.senate.gov/ newsroom/press-releases/in-wake-of-supreme-court-decision-freeing-states-to-legalize-sportsbetting-schumer-proposes-desperately-needed-federal-framework-to-protect-consumers-and-integrity-of-sports-as-state-legislatures-begin-lawmaking-efforts, accessed March 2, 2020 [hereinafter Schumer proposal]; Darren Rovell, Senate Minority Leader Chuck Schumer suggests federal framework for sports betting, ESPN (Aug. 29, 2018), https://www.espn.com/chalk/story/ / id/24511871/chuck-schumer-suggests-federal-framework-sports-betting, accessed March 2, 2020. 
- duties to advertise responsibly (not target young people under 21), properly disclose the dangers of betting, and provide responsible gambling resources. ${ }^{18}$

Suggesting that state legislatures may not share his vision and implying states could not adequately regulate legalized sports wagering, Schumer stated, "As state legislatures develop new legislation in the weeks and months ahead, I hope they will take these principles under consideration. I also support the efforts in the Congress to debate and develop bipartisan federal legislation that would adhere to these principles." 19 By this time most state legislatures had finished their work and would not reconvene until 2019.

At the time that Schumer released his federal framework, there were four states with legalized sports betting offering wagers: Nevada, Delaware, New Jersey, and Mississippi. All four of these states require patrons placing sports wagers to be 21 . State regulators already require mandatory reporting for all suspicious transactions, ${ }^{20}$ and the Nevada Gaming Control Board, in particular, already had a decades-long history of working with sports book operators, leagues, the NCAA, collegiate athletic conferences, and various sports teams to share information and identify irregular activity.

On August 30, 2019, the day after Schumer released his federal framework, sports betting was live in West Virginia. ${ }^{21}$ Not quite three months later, Rhode Island launched its sports betting on November 26, 2018. ${ }^{22}$ There were now six states in the US offering legalized sports betting in their jurisdictions.

In early December 2018, making good on the promise made the day PASPA was repealed, Hatch began to circulate a "discussion draft" of potential legislation for a federal sports betting regime. ${ }^{23}$ By December 4, 2018, the media had

\footnotetext{
18 See Schumer proposal supra note 17.

19 Id.

${ }^{20}$ Nevada Gaming Control Board, Suspicious Wagering Report Instructions, Nv. GAmING Comm'n, https://gaming.nv.gov/modules/showdocument.aspx?documentid=2229, accessed March 19, 2020 [hereinafter State of Nev. Gaming Control Board].

${ }^{21}$ Bart Shirley, Sing It From The Mountaintops! West Virginia Sports Betting Is Live!, Play USA (Aug. 30, 2018), https://www.playusa.com/west-virginia-sports-betting-launch-early/, accessed March 2, 2020.

${ }^{22}$ Kim Kalunian, First legal sports bets placed at Twin River Casino, WPRI.com (Nov. 26, 2018), https://www.wpri.com/news/first-legal-sports-bets-placed-at-twin-river-casino/, accessed March 2, 2020 .

${ }^{23}$ David Purdam, Congress pushing for federal sports betting oversight, ESPN (Dec. 4, 2018), https://www.espn.com/chalk/story//id/25453710/congress-pushing-federal-sports-betting-oversight, accessed March 2, 2020; Federal Sports Betting Bill Form Orrin Hatch Deserves Some Side-Eye, Fuush Draw (Dec. 11, 2018), https://www.flushdraw.net/news/federal-sports-betting-billfrom-orrin-hatch-deserves-some-side-eye/, accessed March 2, 2020; Dustin Gouker, Feds Would Have To Approve State Sports Betting Laws Under New Draft Bill In Congress, Legal Sports REP. (Dec. 4, 2018), https://www.legalsportsreport.com/26545/federal-sports-betting-bill-2018/, accessed March 3, 2020. The draft legislation is sometimes referred to as the Hatch Act.
} 
procured a copy and published it. ${ }^{24}$ The week before Christmas, on December 19, 2018, the bill that would come to be known as the Sports Wagering Market Integrity Act (SWMIA), ${ }^{25}$ was introduced in the U.S. Senate in a bipartisan effort by Hatch ${ }^{26}$ and Schumer. ${ }^{27}$ The bill was referred to the Judiciary Committee. No hearings were scheduled, and no further action was taken. The bill was dead when Congress adjourned January 3, 2019. ${ }^{28}$

In 2019, state legislatures went to work.

\section{Federal Interference Is Unwarranted}

The Tenth Amendment of the U.S. Constitution states, "The powers not delegated to the United States by the Constitution, nor prohibited by it to the States, are reserved to the States respectively, or to the people." ${ }^{29}$ In the US, gambling has been within the purview of the states for hundreds of years as they vacillated between regulating and prohibiting it. ${ }^{30}$ For example, all 13 colonies offered lotteries as a means to generate revenue for the state but later abolished them. Poker and horseracing were available as the US expanded. Horseracing all but disappeared at the turn of the 20th century. Poker was largely unscathed and was only prohibited from 1910-1915 before its resurgence, while casinos and table games flourished in western mining towns, particularly Nevada.

As early as 1949, Nevada has offered legal wagering on sports. ${ }^{31}$ In 1951, a $10 \%$ federal tax on legal sports betting handle in Nevada propelled "legitimate

\footnotetext{
${ }^{24}$ Gouker, supra note 23.

${ }_{25}$ S. 3793, 115th Congress, 2d Session, https://www.congress.gov/bill/115th-congress/senate-bill/3793, 2018.

${ }^{26}$ Senators Schumer and Hatch file federal sports betting bill, IGAMING Bus. (Dec. 19, 2018), https://www.igamingbusiness.com/news/senators-schumer-and-hatch-file-federal-sports-bettingbill, accessed March 2, 2020. Senator Hatch was the sponsor of the bill. See Congress.Gov, https:// www.congress.gov/bill/115th-congress/senate-bill/3793, accessed March 2, 2020.
}

27 Schumer, Hatch Introduce Bipartisan Sports Betting Integrity Legislation (Dec. 19, 2018), https:/www.democrats.senate.gov/newsroom/press-releases/schumer-hatch-introduce-bipartisan-sports-betting-integrity-legislation, accessed March 2, 2020. Senator Schumer was a co-sponsor of the bill. See Congress.Gov, https://www.congress.gov/bill/115th-congress/senate-bill/3793/ cosponsors?searchResultViewType=expanded\&KWICView=false, accessed March 3, 2020.

${ }^{28}$ History, Art \&Archives - List of All Sessions, U.S. House of Representatives, (Mar. 2, 2020) https://history.house.gov/Institution/Session-Dates/All/.

${ }^{29}$ U.S. Const. Amend. X.

30 S. 3793, 115th Congress, 2d Session, https://www.congress.gov/bill/115th-congress/senate-bill/3793, 2018, Finding (9), p. 5; Anthony N. Cabot and Keith Miller, The Law of Gambling and Regulated Gambling: Cases and Materials, “The History and Basics of Gambling, 3-7 (Carolina Academic Press, 2011); Brett Smiley, A History of Sports Betting in the United States: Gambling Laws and Outlaws, SPORTs Hande (Nov. 13, 2017), https://sportshandle.com/gambling-laws-legislation-united-states-history/, accessed March 11, 2020. For a fuller explanation see Cabot and Miller.

${ }^{31}$ Richard N. Velotta, Legalized Sports Wagering Elsewhere Might Not Affect Nevada Much, L.V. SUN (Jan. 6, 2013), https://lasvegassun.com/news/2013/jan/06/legalized-sports-wagering-elsewhere-might-not-affe/. 
operators either out of business or into the untaxed underground." 32 Outside of Nevada the appetite for sports betting fostered an illegal market with ties to organized crime..$^{33}$ Despite the federal government's attempts to regulate illegal gambling and sports wagering through the Federal Wire Act, ${ }^{34}$ The Travel Act of 1961, ${ }^{35}$ the Interstate Transportation of Wagering Paraphernalia Act of 1961, ${ }^{36}$ the Sports Bribery Act of $1964,{ }^{37}$ and the Illegal Gambling and Business Act of $1970,{ }^{38}$ "illegal bookmaking continued and actually proliferated in the " $70 \mathrm{~s}$ and '80s." 39 Indeed, Congress has had very little interest in prohibiting gambling, preferring to leave it to the states. ${ }^{40}$

\section{A. States, Tribes, and Territories Are Capable of Regulating Gaming}

The first sentence of the preamble of SWMIA puts the reader on notice that the federal government is once again interested in interfering with state regulated gambling and sports betting in the US, "To acknowledge the rights of States with respect to sports wagering and to maintain a distinct Federal interest in the integrity and character of professional and amateur sporting contests, and for other purposes." ${ }^{41}$ Perhaps Congress doesn't already have enough to deal with. ${ }^{42}$

How could the federal government possibly know more about gaming regulation than the State of Nevada, which has been legislating on gaming issues

\footnotetext{
${ }^{32}$ David G. Schwartz, Why Congress Should Repeal a Federal Tax on Sports Betting, CDC GAMING REPORTs, Inc. (Mar. 11, 2015), https://www.cdcgamingreports.com/commentaries/whycongress-should-repeal-a-federal-tax-on-sports-betting/

33 Smiley supra note 30.

3418 U.S.C. $\$ 1084$ (2018).

3518 U.S.C. $\S 1952$ (2018).

3618 U.S.C. $\S 1953$ (2018).

3718 U.S.C. $§ 224$ (2018).

3818 U.S.C. $\$ 1955$ (2018).

39 Smiley supra note 30.

40 U.S. v. DiCristina, 886 F. Supp. 2nd 164, 204-205, 223 (E.D.N.Y. 2012).

${ }^{41}$ S. 3793, 115th Congress, 2nd Session, https://www.congress.gov/bill/115th-congress/senate-bill/3793, 2018.

42 See Tim Busch, Let's show Congress how to cooperate on immigration reform, THE HiLl (Mar. 10, 2020), https://thehill.com/opinion/immigration/486048-lets-show-congress-how-to-cooperate-on-immigration-reform, accessed March 25, 2020; Maureen Groppe, Jason Lalljee \& Matt Wynn, Poll: Americans don't expect Congress to act on gun laws, USA TodAY (Sept. 9, 2019), https://www.usatoday.com/story/news/politics/2019/09/09/gun-control-most-americans-dontexpect-congress-pass-new-laws/2151086001/, accessed March 25, 2020; See also Tom Orlik et al., Coronavirus Could Cost the Global Economy \$2.7 Trillion. Here’s How, Bloomberg (Mar. 6, 2020), https://www.bloomberg.com/graphics/2020-coronavirus-pandemic-global-economic-risk/, accessed March 25, 2020.
} 
since $1869,{ }^{43}$ particularly with regard to regulating legal sports betting? ${ }^{44}$ Or the Nevada Gaming Control Board, with its nearly 60 years of regulating all forms of gaming? ? $^{5}$

Contained in Section 2. Findings. (1). is a not-so-subtle, yet perplexing, nod to Nevada, "In 1992, Congress enacted the Professional and Amateur Sports Protection Act ... to ban sports wagering in most states, finding that 'sports gambling conducted pursuant to State law threatens the integrity and character of, and public confidence in professional and amateur sports.",

Fifteen years earlier, the Nevada Legislature established the public policy for gaming, by enacting the following:

The legislature hereby finds, and declares to be the public policy of this state, that:

(a) The gaming industry is vitally important to the economy of the State and the general welfare of the inhabitants.

(b) The continued growth and success of gaming is dependent upon public confidence and trust that licensed gaming ... [is] conducted honestly and competitively ... [and] that gaming is free from criminal and corruptive elements.

(c) Public confidence and trust can only be maintained by strict regulation of all persons, locations, practices, associations and activities related to the operation of licensed gaming establishments, the manufacture, sale or distribution of gaming devices and associated equipment ...

(d) All establishments where gaming is conducted ... must therefore be licensed, controlled and assisted to protect the public health, safety, morals, good order and general welfare of the inhabitants of the State ... and to preserve the competitive economy and policies of free competition of the State of Nevada. ${ }^{46}$

This general philosophy has directed Nevada's legalized gambling market for more than 40 years. ${ }^{47}$

That same year, the New Jersey Division of Gaming Enforcement (DGE) was created ${ }^{48}$ Its primary responsibility "to ensure the integrity of the casino gaming industry in the State of New Jersey ... to protect the public interest by maintaining a legitimate and viable industry, free from the influences of organized crime, and assuring the honesty, good character and integrity of casino

\footnotetext{
${ }^{43}$ Board Information Packet, p. 6, https://gaming.nv.gov/modules/showdocument.aspx?documen-

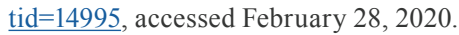

${ }^{44}$ Velotta supra note 31.

${ }^{45} \mathrm{Id}$.

46 Nev. Rev. Stat. § 463.0129 (1999).

${ }^{47} \mathrm{Id}$. Though amended 10 times the statute has not changed in fundamental ways since its enactment over 40 years ago.

48 The State of New Jersey, Department of Law \& Public Safety, Office of the Attorney General, Division of Gaming Enforcement, About, https:/www.nj.gov/oag/ge/mission\&duties.htm, accessed March 3, 2020.
} 
owners, operators, employees and vendors.' ${ }^{49}$ Like Nevada, the DGE uses a "strict regulation" standard. ${ }^{50}$

For decades, states and tribal jurisdictions have demonstrated their ability to operate various forms of gambling by regulating with fidelity while maintaining the highest levels of integrity. By contrast, the "federal government has historically played no role in the discharge of the traditional regulatory functions of licensing, enforcement, and audit." 51 The fact that "Congress has no real expertise in establishing gaming regulatory regimes," 52 makes it that much more challenging to accept the premise that the federal government could somehow better regulate legalized sports betting. Nor has it wanted to. ${ }^{53}$

\section{B. Imposing a Federal Regulatory Structure Would Be Disruptive and Counterproductive}

By the time this federal legislation was introduced states already had sports betting well under control. In just a few short months, adding to Nevada's legal sports betting history of 70 years, ${ }^{54}$ were newcomers Delaware, ${ }^{55}$ New Jersey, ${ }^{56}$ Mississippi, ${ }^{57}$ West Virginia, ${ }^{58}$ and Rhode Island. ${ }^{59}$ As of the writing of this article, several states ${ }^{60}$ and The District of Columbia ${ }^{61}$ have live legalized sports wagering. The Commonwealth of Puerto Rico ${ }^{62}$ and a handful of $\operatorname{states}^{63}$ have legalized sports betting but don't yet offer it, and about a third of the states have

\footnotetext{
${ }^{49} I d$.

${ }^{50} I d$.

${ }^{51}$ Keith C. Miller \& Anthony N. Cabot, Regulatory Models for Sports Wagering: The Debate Between State vs. Federal Oversight, 8 UNLV Gaming L.J. 153, 156 (2018).

${ }^{52}$ Id. at 174.

53 Iannelli v. United States, 420 U.S. 770, 788 (1975).

${ }^{54}$ Velotta supra note 31

55 Delaware sports betting was live on June 5, 2018.

${ }^{56}$ New Jersey sports betting was live on June 14, 2018.

${ }^{57}$ Mississippi sports betting was live on Aug. 1, 2018.

58 West Virginia sports betting was live on Aug. 30, 2018.

${ }^{59}$ Rhode Island sports betting was live on Nov. 26, 2018.

${ }^{60}$ States with live legal sports betting include Arkansas, Colorado, Delaware, Illinois, Indiana, Iowa, Michigan, Mississippi, Montana, Nevada, New Hampshire, New Jersey, New Mexico, New York, Oregon, Pennsylvania, Rhode Island, Tennessee, and West Virginia.

${ }_{61}$ Washington D.C.'s legal sports wagering went live May 28, 2020

${ }^{62}$ Daniel OBoyle, Puerto Rico governor signs sports betting bill into law, IGAming Bus. (July 31, 2019), https://www.igbnorthamerica.com/puerto-rico-governor-signs-sports-betting-bill-into-law/, accessed June 25, 2020.

${ }^{63}$ States that have authorized legal sports betting but are not yet live include North Carolina, Tennessee, Virginia, and Washington.
} 
entertained sports betting legislation. ${ }^{64} \mathrm{~A}$ few states have determined that a ballot measure is the best way to determine the public's appetite for sports wagering. ${ }^{65}$ Despite acknowledging a state's right to permit and regulate sports betting, the senators determined, “... there is an important role for Congress to set standards for sports wagering and provide law enforcement with additional authority to target the illegal sports wagering market and bad actors in the growing legal sports wagering market." ${ }^{\prime 66}$ The various US jurisdictions with legal sports betting enterprises have robust regulatory systems and have demonstrated the ability to regulate with integrity. It seems that the doubts Congress has regarding the

${ }^{64}$ Legal Sports Betting in the U.S., Am. Gaming Ass'n, https://www.americangaming.org/wp-content/uploads/2020/01/AGA-Sports-Betting-Map-2020.pdf, accessed March 11, 2020. During the 2020 legislative session 21 states had active legislation to legalize sports betting. See, Legal Sports Betting in the US, Interactive Map - Legal landscape as of March 13, 2020, Am. Gaming Ass'N, https://www.americangaming.org/wp-content/uploads/2020/01/AGA-Sports-Betting-Map-2020. pdf, accessed March 25, 2020. States that were actively considering legalizing sports betting during the 2020 legislative session or via a ballot measure include Alabama, Alaska, Arizona, California, Connecticut, Hawaii, Kansas, Louisiana, Maryland, Massachusetts, Minnesota, Missouri, Nebraska, Ohio, South Dakota, Vermont, and Virginia.

${ }^{65}$ Voters in Louisiana, Maryland and South Dakota will see sports betting measures on their ballots in November 2020. Louisiana Sports Betting Parish Measures, BallotPedia (2020), https:// ballotpedia.org/Louisiana_Sports_Betting_Parish_Measures_(2020), accessed July 1, 2020; Maryland Sports Betting Expansion Measure, BALlotPeDIA, https://ballotpedia.org/Maryland Sports_Betting_Expansion_Measure (2020), accessed June 26, 2020; South Dakota Constitutional Amendment B, Deadwood Sports Betting Legalization Amendment, BallotPedia, https:// ballotpedia.org/South_Dakota_Constitutional_Amendment_B, Deadwood_Sports_Betting_Legalization_Amendment_(2020), accessed June 26, 2020. A coalition of Native American tribes in California were given the go-ahead to circulate petitions in an effort to obtain enough signatures to get a sports betting measure on the California ballot in November 2020. Due to the outbreak of COVID-19, resulting in a worldwide pandemic and a March 19, 2020. shelter in place order in California, signature gathering efforts had to be shuttered before the April 21, 2020, deadline. The California tribes obtained a court-ordered time extension in which to gather the signatures. They have until October 12, 2020, to obtain the required signatures to qualify their sports betting initiative for the November 2022 ballot. See Patrick McGreevy, Tribal Casinos Sue California for More Time to Qualify Legal Sports Betting Measure Amid Coronavirus, L.A. Times (June 9, 2020), https://www.latimes.com/california/story/2020-06-09/coronavirus-tribal-casinos-sports-bet-

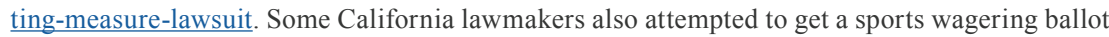
measure passed but ended that effort on June 22, 2020, due to time constraints and tribal opposition. See Jill R. Dorson, Judge Rules for California Tribes on Sports Betting Initiative Extension, SPORTs HANDLE (July 2, 2020), https://sportshandle.com/ca-tribes-october-sports-betting/, accessed August 19, 2020. See also Associated Press, California Lawmakers End Bid to Put Legalized Sports Betting On November Ballot, KTLA (June 22, 2020), https://ktla.com/news/california/california-lawmakers-end-bid-to-put-legalized-sports-betting-on-november-ballot/; see also Christopher Palmeri, California to Pull Sports Betting Bill After Tribal Opposition, Bloomberg (June 22, 2020), https://www.bloomberg.com/news/articles/2020-06-22/california-to-pull-sports-betting-bill-after-tribal-opposition.

${ }^{66}$ S. 3793, 115th Congress, 2nd Session, https://www.congress.gov/bill/115th-congress/senate-bill/3793, 2018, Finding (10), p. 5. 
states and tribal jurisdiction's ability to effectively regulate sports wagering are misplaced. There have been no sports integrity scandals involving sports book operators or state regulatory agencies during the state rollout of legal sports betting post-PASPA. By contrast, some sport organizations have been dealing with challenges that undermine the integrity of the games they offer. ${ }^{67}$

\section{The Federal Government Has No Experience or Proficiency in Regulating Gambling Whereas States and Tribal Jurisdictions Do.}

Rather than recognizing that for decades states and tribal jurisdictions have regulated gambling appropriately and successfully, SWMIA attempts to impose federal oversight by defining a state sports wagering program as "a program administered and overseen by a State pursuant to an application approved by the Attorney General ..." ${ }^{68}$ Section 102 (a) requires states to obtain authorization to conduct sports wagering by "submit[ting] an application to the Attorney General ..." Section 102 (b) causes considerable concern as it requires, "(1) IN GENERAL. - Not later that 180 after the date on which the Attorney General receives a complete application under this section the Attorney General shall approve the application unless the Attorney General determines that the proposed State sports waging program does not meet the standards set forth in section 103." 69

It is ironic that Congress, which traditionally has played no role in and "has no real expertise in establishing gaming regulatory regimes," ${ }^{70}$ went so far as to make findings within SWMIA that gaming has historically been regulated at the State level, ${ }^{71}$ now wants to establish a federal sports betting regulatory framework through the U.S. Attorney General's office. It seems absurd that the U.S. Attorney General's office would make the determination as to whether or not a state's sport betting regulatory process is up to its standards? Currently there are no federal standards. Language throughout the bill demonstrates that it borrowed heavily from Nevada's sports betting regulatory process. ${ }^{72}$ Establishing a federal

\footnotetext{
${ }^{67}$ Cassandra Negley, ESPN report concludes Tim Donaghy did conspire to fix NBA games, YAHOo! SpORTs (Feb. 19, 2019), https://sports.yahoo.com/espn-report-calculates-6155-1-oddstim-donaghy-randomly-made-calls-favored-bets-173109058.html, accessed March 11, 2020; R.J. Anderson \& Mike Axise, Astros sign stealing scandal: What to know about MLB's penalties against Houston, CBS SPORTs (Jan. 18, 2020), https://www.cbssports.com/mlb/news/astros-signstealing-scandal-what-to-know-about-mlbs-penalties-against-houston/, accessed March 11, 2020; Brent Schrotenboer, Steve Berkowitz \& Matt Wynn, Cheating Allegation, corruption scandal don't slow men's basketball coaches' pay, USA ToDAY, (Mar. 11, 2020), https://www.usatoday.com/ story/sports/ncaab/2020/03/11/college-basketball-coaches-salaries-schools-pay-more-after-fbiprobe/5012939002/, accessed March 11, 2020.

${ }^{68}$ S. 3793, 115th Congress, 2nd Session, https://www.congress.gov/bill/115th-congress/senate-bill/3793, 2018, Section 3. Definitions. (24), p. 13.

69 The Sports Wagering and Market Integrity Act of 2018, Title I, Section 102(b)(1), p. 18.

${ }^{70}$ Keith C. Miller \& Anthony N. Cabot, Regulatory Models for Sports Wagering: The Debate Between State vs. Federal Oversight, 8 UNLV Gaming L.J. 153, 156 (2018).

${ }^{71}$ S. 3793, 115th Congress, 2nd Session, https://www.congress.gov/bill/115th-congress/senate-bill/3793, 2018, Finding (9), p. 5.

72 See Nevada Gaming Comm'n Regulations 6.090, 6.100, 22.061, 22.121, 140, and 22.2105 (proposed regulation at the time SWMIA was being drafted).
} 
sports betting regulatory structure still does not assure that the U.S. Attorney General's office has the requisite skill, resources, and experience to appropriately regulate an industry that operates on a privileged license $\mathrm{e}^{73}$ and requires regulatory clarity to operate. From the way SWMIA is drafted, it appears that states would continue to regulate sports betting day to day, but they would still be subject to federal oversight, though it appears that once sports betting regulations are "approved" the U.S. Attorney's Office would only amount to a "rubber stamp." This, then, begs the question: What is the value add for imposing a federal sports betting regulatory scheme?

\section{Effective State and Tribal Gambling Regulatory Structures Will Most Likely Languish Waiting for Federal Approval.}

Equally unclear is how long the federal review process would take. While the default is that the U.S. Attorney General shall approve state applications for legalized sports wagering, the U.S. Attorney General's office has up to 180 days to determine whether or not a state sports wagering regulatory process meets the standards outlined in Section $103 .^{74}$ Unfortunately for the states operating legalized sports wagering, SWMIA simply fails to address whether or not sports wagering operations would be allowed to continue to operate during the review. It could be economically devastating to states, their economies, and their state budgets to the extent sports betting operations would be shuttered during the review. As of March 22, 2020, a combined total of $\$ 180,809,444.00$ in tax revenues was generated for the states with live sports betting. ${ }^{75}$ Public health concerns brought about by the COVID-19 global pandemic led to the closure of all US brick and mortar casinos. ${ }^{76}$ Though US casino closing and re-opening dates vary by state, every casino was shut down as of March 25, 2020, while May 7, 2020,

\footnotetext{
${ }^{73}$ As the first state to legalize gambling in the United States, and the only state offering legal gambling at the time, the 1977 Nevada Legislature declared the public policy of the State of Nevada to be that, "No applicant for a license ... has any right to a license or the granting of the approval sought. Any license issued ... is a revocable privilege, and no holder acquires any vested right therein or thereunder.” See NRS 463.0129. Other jurisdictions with legal gambling have followed suit. Because the granting of a gaming license is discretionary, no property rights attach to it. If the regulatory body that granted a license determines that a license holder is no longer suitable to hold a gaming license, the license and with it the ability to work in the gaming industry is lost.

74 S. 3793, 115th Congress, 2nd Session, https://www.congress.gov/bill/115th-congress/senate-bill/3793, 2018, Section 102(b)(1), p. 18.

75 US Sports Betting Revenue and Handle, LEGAL SPORTs ReP. https://www.legalsportsreport.com/ sports-betting/revenue/, accessed February 28, 2020. Due to the COVID-19 worldwide pandemic, all US casinos were closed as of March 25, 2020. All US commercial casinos are now closed, YoGONET, (Mar. 25, 2020), https:/www.yogonet.com/international/noticias/2020/03/25/52723-all-uscommercial-casinos-are-now-closed, accessed July 1, 2020. See also Howard Stutz, 100 percent: Every one of the nation's commercial casinos will be closed by Wednesday, CDC GAMING REPORTS, (Mar. 24, 2020), https://www.cdcgamingreports.com/100-percent-everyone-of-the-nations-commercial-casinos-will-be-closed-by-wednesday/.

${ }^{76}$ David Purdum, 100\% of U.S. casinos to be closed amid coronavirus pandemic, ESPN, (Mar. 24, 2020), https://www.espn.com/chalk/story//id/28947622/100-us-casinos-closed-wednesday, accessed June 27, 2020.
} 
saw the first casino re-openings. ${ }^{77}$ When analyzing cumulative sports betting taxation figures as of June 23, 2020, states with legalized sports betting realized a combined total of $\$ 210,237,290.00$. Though lower than it would otherwise be due to tax revenues not realized by Arkansas, Illinois, Montana, New Mexico, and Oregon because they had zero handle (due to casino closures) and therefore collected zero tax,${ }^{78}$ these figures are illustrative of how economically devastating it could be for states if sports wagering operations were required to cease during a federal review process.

While the legislation doesn't address the issue of whether or not states with legalized sports betting regulatory structures would be allowed to continue their sports betting operations while its regulations are under review, at a minimum, SWMIA injects uncertainty into the commercial market. Under SWMIA, the U.S. Attorney General has broad discretion to deny a state the ability to operate sports wagering, ${ }^{79}$ or to revoke the approval of a state to operate sports wagering at any time, if the determination is made that the state sports wagering program does not meet one or more of the standards in Section $103 .{ }^{80}$ By providing the U.S. Attorney General with emergency revocation power, the federal government has created a potential pathway for the federal government to bypass the state legislative and rule-making processes. Further confusion arises because the legislation does not clearly articulate what the process will be if a state's sports betting regulations are rejected under Section 102(b)(1) ${ }^{81}$ For example, would the U.S. Attorney General's office make amendments directly to a state's sports betting regulation, require state regulators to rethink the necessary changes and wait through another review process that could take up to 180 days, or establish some other process?

\section{Establishing a Federal Regulatory Scheme Will Be a Lengthy and Disruptive Process.}

A federal regulatory regime for legalized sports betting would take several years to establish and chaos would be injected into the gaming industry as at least 19 states and the District of Columbia would be subject to a review of their sports wagering regulations for up to 180 days. $^{82}$

If each state with legal sports wagering were to undergo a federal review and be deemed compliant with federal standards, it begs the question as to why

\footnotetext{
${ }_{77}$ Id. Contessa Brewer, 'Cabin fever' leads to big reopening weekend for South Dakota casinos, CNBC (May 12, 2020), https://www.cnbc.com/2020/05/11/cabin-fever-leads-to-big-reopeningweekend-for-south-dakota-casinos.html, accessed June 27, 2020.

78 US Sports Betting Revenue And Handle, LEGAL SPORTs REP. https://www.legalsportsreport.com/ sports-betting/revenue/, accessed June 26, 2020.

79 S. 3793, 115th Congress, 2nd Session, https://www.congress.gov/bill/115th-congress/senate-bill/3793, 2018, Section 102(b)(2), p. 18.

${ }^{80}$ S. 3793, 115th Congress, 2nd Session, https://www.congress.gov/bill/115th-congress/senate-bill/3793, 2018, Section 102(f)(1), p. 19.

${ }^{81}$ The Sports Wagering and Market Integrity Act of 2018, Title 1, Section 102(b)(1) \& (2), p. 18.

${ }^{82}$ S. 3793, 115th Congress, 2nd Session, https://www.congress.gov/bill/115th-congress/senate-bill/3793, 2018, Section 102(d)(1), p. 18.
} 
federal oversight is even necessary. Should an unfortunate state be found to have inadequate regulations per the federal review, while operating, how could the federal government possibly repair the public's loss of confidence in that state's gaming regulations and the products it offers?

Even if a state's sports betting regulations are approved by the U.S. Attorney General's office on the first submission, states will be subject to the disruption the renewal process injects as Section 103 (d) requires a review of state sports betting regulations every three years. ${ }^{83}$ The additional barriers contemplated by the federal review would prevent the states from being proactive and responsive to the ever-changing sports betting environment, whereas in Nevada the process for regulatory change is quite nimble and can occur in relatively short order. Nevada Revised Statute 463.145 sets out the requirements for regulatory change, which includes a short 30-day notice before the commission meeting at which a proposed regulatory change can take place. ${ }^{84}$

A comprehensive federal system of regulation for sports betting is ill-advised and would only serve to create additional barriers, add unnecessary complication, result in needless delays, increase the cost of legalized sports wagering products and inject uncertainty into the industry.

\section{Finding Solutions for Non-Existent Problems}

SWMIA appears to be a solution in search of problems. As a privileged license industry, ${ }^{85}$ gaming operators are only allowed to expose for play or offer and accept wagers under the most stringent state government regulations. In every state with legalized gambling, gaming licensees must not only adhere to substantial statutory, regulatory, and internal controls standards, they are required to create their own system of minimum internal control standards (MICS). SWMIA also requires sports book operators to create MICS, though the provision is superfluous because state regulators have already imposed this requirement. ${ }^{86}$

In Nevada, stringent accounting and process requirements are imposed on its sports book operators, and audits are conducted regularly by the Nevada Gaming Control Board.$^{87}$ Some of those requirements include capturing and retaining

\footnotetext{
${ }^{83}$ S. 3793, 115th Congress, 2nd Session, https://www.congress.gov/bill/115th-congress/senate-bill/3793, 2018, Section 103(d), p. 19.

${ }^{84}$ NRS 463.145(1)(a)

85 Those operating common types of businesses have a "right" to do so. A license from the state is required to operate a gambling business. Because there is no "right" to operate legal gambling it is said to be a "privileged" business. Shannon Bybee, The Legal Status of Gaming and Its Impact on licensing, 2 UNLV Gaming Research \& Rev. J. 61, 61 (1995).
}

${ }^{86}$ S. 3793, 115th Congress, 2nd Session, https://www.congress.gov/bill/115th-congress/senate-bill/3793, 2018, Section 103(b)(16), p. 47.

${ }^{87}$ See Nev. Gaming Comm’n Reg. § 5.013 (2019), Nev. Gaming Comm’n Reg. § 5.115 (2019), Nev. Gaming Comm'n Reg. § 5.190 (2019), Nev. Gaming Comm'n Reg. § 5.225-5.240 (2019); see also Nev. Gaming Comm'n Reg. § 6 (2019), Nev. Gaming Comm’n Reg. § 14.010 (2019), Nev. Gaming Comm'n Reg. § 22 (2019), Nev. Gaming Comm'n Reg. § 26B (2019), Nev. Gaming Comm'n Reg. § 26C (2019); see State of Nev. Gaming Control Board, Minimum Internal Control Standards, RACE AND SPORTS (2008), https://gaming.nv.gov/modules/showdocument.aspx?documentid=4549. 
information about every aspect of the sports wagering process, including:

- every wager placed,

- ensuring appropriate information is captured on the wagering slip, ${ }^{88}$

- each paid win amount,

- event results and any results changes,

- odds changes,

- any voids and who provided the authorization for the voids,

- data necessary for financial audits of the operations of the sports book, ${ }^{89}$

- processes and procedures utilized by the sports books, ${ }^{90}$

- maintenance of minimum reserve and bankroll requirements, ${ }^{91}$ and

- surveillance requirements. $^{92}$

\section{A. Limitations on Wagers}

SWMIA attempts to establish limitations on the types of legal wagers that can be offered by requiring that a wager be "expressly approved" by the state regulator. ${ }^{93}$ Interestingly, New Jersey seems to be headed in this direction and may soon require express approval of wagers on sports events. ${ }^{94}$

Nevada regulates sports wagers from the premise that wagers are generally permitted ${ }^{95}$ unless they are expressly prohibited. ${ }^{96}$ The only exception is for "other events," ${ }^{97}$ which are wagers offered on non-sporting events such as virtual events, esports or the Oscars. Interestingly, SWMIA does not address non-sporting events, even though it is not unusual for a sports book operator to take wagers on non-sporting events.

\footnotetext{
88 See generally State of Nev. Gaming Control Board, supra note 20.

89 See State of Nev. Gaming Control Board, supra note 20.

90 See State of Nev. Gaming Control Board, supra note 20; STATE BAR OF Nev. PUBLiCATIONS DEP'T \& GAMING LAW SECTION OF THE STATE BAR OF NEV., NEVADA GAMING Law Practice and Procedure Manual, Sec. 15.01 (2016).

91 Nev. Gaming Comm'n Reg. § 6.150.

92 See Nev. Gaming Comm'n Reg. § 5A (2019).

${ }^{93}$ S. 3793, 115th Congress, 2nd Session, https://www.congress.gov/bill/115th-congress/senate-bill/3793, 2018, Section 103(b)(1)(C)(1), p. 22.

${ }_{94}$ State of New Jersey, 219th Legislative Session, Assembly Bill 637. The New Jersey Assembly passed on July 30, 2020. It was received by the Senate on August 3, 2020, and awaits further action.

95 Nev. Gaming Comm’n Regulation \$22.120 (2019).

96 Nev. Gaming Comm'n Regulation § 22.1205 (2019).

97 Nev. Gaming Comm'n Regulation § 22.1201 (2019).
} 
SWMIA also provides a provision to allow sport organizations to submit requests to regulatory bodies to limit or exclude wagering on their sporting events if it is "necessary to maintain contest integrity." 98 However, there is nothing that prevents sport organizations from submitting such a request for any reason. ${ }^{99} \mathrm{Be}-$ cause sport organizations can already petition state regulators to limit or exclude action on their events, there is nothing more to be gained by making it a federal mandate, unless the intent of the legislation is to put pressure on state regulators to yield to the sports leagues' demands.

\section{B. Wagering Prohibitions}

\section{Anyone Under the Age of 21.}

Section 103(b)(4) mandates a legal age of 21 for the placement of sports wagers. For the majority of states in the US, the legal age to place a wager is already 21. ${ }^{100}$ A smattering of states, including Georgia, Idaho, Kentucky, Minnesota, Montana, New Hampshire, Oklahoma, Rhode Island, South Carolina, Texas,

\footnotetext{
${ }_{98}$ S. 3793, 115th Congress, 2nd Session, https://www.congress.gov/bill/115th-congress/senate-bill/3793, 2018, Section 103(b)(1)(C)(1), p. 22.

${ }_{99}$ Matt Bonesteel, MLB asked Nevada to stop taking bets on spring training games. Nevada said no., WASH. Post (Feb. 26, 2019), https://www.washingtonpost.com/sports/2019/02/26/mlb-askednevada-stop-taking-bets-spring-training-games-nevada-said-no/, accessed March 18, 2020. See also David Purdum, NGCB declines MLB's request to prohibit betting on spring training games, ESPN (Feb. 25, 2019), https://www.espn.com/chalk/story//id/26080224/mlb-asks-ngc-prohibitbetting-spring-training-games, accessed March 28, 2020.

100 Arizona, Arkansas, California, Colorado, Connecticut, Delaware, Florida (21 for casino gaming, 18 for poker/Bingo), Illinois, Indiana, Iowa, Louisiana, Maryland, Massachusetts, Michigan (2007 tribal compact) Mississippi, Missouri, Nevada, New Jersey, New Mexico, New York (casinos), North Carolina (Class III gaming), North Dakota, Ohio, Oregon, Pennsylvania, South Dakota, West Virginia, and Wyoming. State of Play Interactive Map, Regulatory Fact Sheet, Ам. GAMING Ass'N, https://www.americangaming.org/state-of-play/, accessed July 3, 2020. In Alaska, the age for participation in gambling activities varies. The legal ages are as follows: pull tab products, 21 (AS 05.15.187(e)), Bingo, 19 (AS 05.15.180(f)), and Calcutta pools, 18 (AS 05.15.180(h)). Maine requires slot players to be 21. Maine Revised Statutes, §954(2). In Tennessee, the legal age to place a sports wager is 21. Sports Gaming License Rules, Regulations and Standards, 15.1.3(G), Tn. Lottery https://tnlottery.com/wp-content/uploads/2020/06/TN_Rules_Regulations-___Revised-061620.pdf, accessed July 1, 2020; and according to Legal Sports Report, the legal age to place a sports wager in Virginia is 21. Virginia Sports Betting, Legal Sports ReP., https://www. legalsportsreport.com/virginia/, accessed July 1, 2020.
} 
Vermont, Washington, and Wisconsin, have a legal gambling age of $18 .{ }^{101}$ Of these states, only Montana, New Hampshire, and Rhode Island are actually live with legalized sports betting. ${ }^{102}$ Alabama and Nebraska allow for gambling at age $19,{ }^{103}$ while Hawaii and Utah criminalize participation in gambling activities. ${ }^{104}$

For the rest of the states with a legal gambling age under 21, until sports betting is legal in those jurisdictions, it is a non-issue. For states considering sports betting legislation, state legislatures have the power to change the legal gambling age to 21 if they so desire.

\section{Wagering by Insiders}

The legislation also prohibits "insiders" such as athletes, coaches, officials, employees of sport organizations, clubs or teams, employees of players or official unions of sport organizations, and credentialed or accredited individuals from sport organizations with wagering restrictions from placing wagers. ${ }^{105}$

\footnotetext{
${ }_{101}$ In Georgia, the legal age to play Bingo and participate in raffles is 18. Official Code of Georgia Annotated \$16-12-58, and §16-12-22.1(i). In Kentucky and South Carolina, the legal age to play the lottery is 18. See KY. LotTERy, https://www.kylottery.com/apps/, accessed July 2, 2020; see also South Carolina Code of Laws \$59-150-250(A). According to Legal Sports Report, the legal age to place a sports wager in New Hampshire is 18. New Hampshire Sports Betting, Legal SPORTS REP., https://www.legalsportsreport.com/nh, accessed July 1, 2020. Participants must be 18 to play Bingo in Texas. Texas Statutes \$2001.418. See also State of Play Interactive Map, Regulatory Fact Sheet, Am. GAming Ass'N, https://www.americangaming.org/state-of-play/, accessed July 3, 2020.

102 Legal Sports Betting in the U.S., Am. Gaming Ass'n, https://www.americangaming.org/ wp-content/uploads/2020/01/AGA-Sports-Betting-Map-2020.pdf, accessed February 28, 2020. Montana launched its sports betting products on March 9, 2020. Sports Wagering, MonT. LotTERY, https://www.montanalottery.com/en/view/sports-wagering, accessed April 21, 2020.

${ }_{103}$ Alabama requires patrons to be 19 when playing Bingo unless accompanied by a parent. Alabama Code \$45-8-150.08. In Nebraska, any form gambling was illegal until 1934 when a series of constitutional amendments began to allow various forms of gambling. Pari-mutuel horse racing when conducted on licensed racetrack enclosures was allowed in 1934, followed by bingo games conducted by nonprofit associations in 1958. In 1967, raffles, lotteries and gift enterprises for charitable and community betterment purposes were approved. Finally, in 1988 horse racing simulcasts were permitted. Nebraska Revised Statute 2-1207. See also Nebraska Revised Statutes, NeB. Legislature, https://nebraskalegislature.gov/laws/statutes.php?statute=2-1207, accessed July 1, 2020; see also Frequently Asked Questions (FAQ’s) About Gambling In Nebraska, NeB. LiQuOR Control Comm'N, https://lcc.nebraska.gov/gambling-faq, accessed July 3, 2020.

104 Hawai'i Revised Statutes §712-1223 and Utah Code §76-10-1102.

105 S. 3793, 115th Congress, 2nd Session, https://www.congress.gov/bill/115th-congress/senate-bill/3793, 2018, Section 103(b)(1)(4)(iii-v), pp. 26-27.
} 
Commendable as this is, there are approximately 18,000 professional athletes in the US alone. ${ }^{106}$ When the other categories of insiders are added, the numbers increase exponentially and are unmanageable. Regulatory compliance by sports book operators would be virtually impossible and there is a strict liability component to the legislation in that Section 4(A) "Prohibit[s] a sports wagering operator from accepting sports wagers ..." ${ }^{\prime 107}$ from the above insiders or face civil penalties of "not more than the greater of $\$ 10,000$ or 3 times the amount of the applicable sports wager."108

Rather than attempt to impose standards upon sportsbooks in Nevada that are impossible to comply with, the Nevada Gaming Control Board and Nevada Gaming Commission took a reasonableness approach while holding gaming licensees to strict standards. Nevada Gaming Commission Regulation 22.1205, Prohibited Wagers, states,

No wagers may be accepted or paid by any book on: ... 2. Any sporting event or other event which the licensee knows or reasonably should know is being placed by, or on behalf of, an official, owner, coach, or staff of a participant or team or participant in that event. Each licensee shall take reasonable steps to prevent the circumvention of this regulation...$^{109}$

Implicit in the federal inclusion of such provisions is the intention that over time the aim would be for direct federal regulation of all sports betting or to make compliance with the federal standards so onerous that operators would not accept the risk and legal sports betting operations would cease. Either way, the states would be denied their ability to regulate.

\section{Wagers on Some Amateur Sports}

Section 103(2)(D) prohibits sports wagers on amateur athletic competitions except the Olympic Games, Paralympic Games, Pan-American Games or any intercollegiate sports. Section 3 of SWMIA incorporates the definition for amateur athletic competition from the Ted Stevens Olympic and Amateur Sports Act. ${ }^{110}$ In that Act, "“amateur athletic competition' means a contest, game, meet, match, tournament, regatta, or other event in which amateur athletes compete."'11

\footnotetext{
${ }^{106}$ How Many Professional Athletes Are There in the U.S.?, Answers (July 18, 2016), https://www. answers.com/Q/How_many_professional_athletes_are there in the US, accessed March 18, 2020 .

107 S. 3793, 115th Congress, 2nd Session, https://www.congress.gov/bill/115th-congress/senate-bill/3793, 2018, Section 101(d)(1), p. 16.

108 S. 3793, 115th Congress, 2nd Session, https://www.congress.gov/bill/115th-congress/senate-bill/3793, 2018, Section 103(b)(1)(4) and Section 103(b)(1)(4)(A), p. 26.

109 Nev. Gaming Comm'n Regulation 22.1205 (2019).

11036 U.S. Code $\S 220501$.

11136 U.S. Code $\S 220501$ (b)(1).
} 
Of the US jurisdictions that offer legal sports betting, none of them allow for action to be taken on non-collegiate amateur sporting events. ${ }^{112}$ While SWMIA makes an exception for states to take bets on college sports if the state regulator approves collegiate bets, ${ }^{113}$ states are clearly showing differences in their public policy priorities. Some state legislatures are allowing wagering on collegiate sports generally, ${ }^{114}$ while other states are allowing wagers on collegiate sports but prohibiting wagers on collegiate teams within their jurisdictions. ${ }^{115}$

Because states are already effectively regulating sports betting activity by prohibiting wagers on amateur athletic events, federal legislation prohibiting these types of wagers is unnecessary and duplicative.

\section{Reporting}

Section $103(13)^{116}$ requires that sports betting operators, “... shall promptly report the information ... for any suspicious transactions to the State regulatory entity."

\footnotetext{
${ }^{112}$ Arkansas Casino Gaming Rules 20.120; Delaware Lottery Sportsbook Wagering Rules, https:// www.delottery.com/Sports-Lottery/Rules/Sportsbooks-Wagering\#4; Delaware Lottery Games, https://www.delottery.com/Sports-Lottery, Illinois Gaming Board, 44 Ill Reg. 2618, 293, https:// www.cyberdriveillinois.com/departments/index/register/volume44/register_volume44 issue 7.pdf; Indiana Gaming Commission, Directive to Sports Wagering Operators, January 22, 2020, https://www.in.gov/igc/files/IGC\%20Directive $\% 20$ on $\% 20$ Betting $\% 20$ Catalogues, $\% 20$ Wagers\%20and\%200ther\%20Events.pdf, Indiana Gaming Commission, Approved Events for Sports Wagering, last updated April 6, 2020; Iowa Racing and Gaming Commission, Sports Wagering and Fantasy Sports Rules 073019, Chapter 11, 491-13.1(99F) "Sports Wagering” and 491-13.2(99F); Michigan Compiled Laws § 432.405; New Mexico Tribal regulation for sports betting are not publicly available; Mississippi Gaming Comm'n Regs. Part 9, Rule 3.11; Montana Lottery, Administrative Rules of Montana (ARM) 2.63.204, https://montanalotterysportsbet. com/\#1580161021712-b71bf487-c423 and https://www.montanalottery.com/en/view/faqs; Nevada Gaming Comm'n Reg. 22.1205; New Hampshire Lottery, https://www.nhlottery.com/Sports/ Mobile-Internet-Sports-Betting; New Jersey Casino Control Commission, NJSA. 5:12A-10; New York, 9 CCR-NY 5329.13; Oregon Lottery, https://sports.oregonlottery.org/most-asked-questions/ and https://sports.oregonlottery.org/live-betting/; Pennsylvania Gaming Control Board, $58 \mathrm{~Pa}$. Code $§$ 1401.6; Rhode Island S 0037 substitute A (2019) (LC000721/Sub A) 42-61.2-1(23) and http://cdn.twinriver.com/wp-content/uploads/RI-HouseRules January2019-002.pdf; and West Virginia, CSR $\S 179-9-7$ (7.1) and (7.2).

113 S. 3793, 115th Congress, 2nd Session, https://www.congress.gov/bill/115th-congress/senate-bill/3793, 2018, Section 103(b)(13), p. 43.

${ }^{114}$ Colorado, Indiana, Iowa, Michigan, Mississippi, Montana, Nevada, Pennsylvania, and Tennessee.

115 Arkansas, Delaware, Illinois, New Hampshire, New Mexico, New Jersey, New York, Oregon, Rhode Island, Washington, Washington D.C., and West Virginia.

116 S. 3793, 115th Congress, 2nd Session, https://www.congress.gov/bill/115th-congress/senate-bill/3793, 2018, Section 103(b)(1)(D), p. 23.
} 
Since the mid-1980s, Nevada gaming regulators have had processes in place for operators to report suspicious transactions to the Nevada Gaming Control Board. Nevada adopted formal regulations for reporting suspicious transactions in $2001 .{ }^{117}$ From 2001 to the present, these regulations outline the process and timing requirements for Nevada sports books to file reports of suspicious transactions with the Board. ${ }^{118}$ Furthermore, identified irregularities, if any, are investigated by the appropriate law enforcement agencies, depending on whether state, federal or a joint investigation is warranted. ${ }^{119}$

\section{E. Investigative Cooperation}

Section $104(15)^{120}$ requires sports wagering operators to “... cooperate with any lawful investigation conducted" by:

- the state regulatory entity;

- federal or state law enforcement; or

- a sport organization, with respect to a sports wager on a sporting event sponsored, organized or conducted by the sports organization;

- placed by or on behalf of [certain individuals]; and

- accepted by the sports wagering operator.

At least with respect to Nevada, this type of investigative cooperation has been ongoing for decades. The Nevada Gaming Control Board and Nevada sportsbooks have formed strong relationships with professional sports leagues and collegiate athletic organizations. For example: ${ }^{121}$

- John "Hot Rod" Williams, a former National Basketball Association (NBA) player, was involved in a point shaving scandal along with four other Tulane players. Las Vegas bookmakers helped uncover this scandal and Tulane dropped its basketball program. ${ }^{122}$

\footnotetext{
117 Nev. Gaming Comm'n Regulation 22.121 (2019).

118 Nevada Gaming Commission Regulation 22.121; Todd Dewey, Las Vegas bookmakers know a fix when they see one, L.V. Rev. J. (Sept. 8, 2017), https://www.reviewjournal.com/sports/betting/ las-vegas-bookmakers-know-a-fix-when-they-see-one/, accessed March 3, 2020.

${ }_{119}$ Id. See also Eamonn Brennan, FBI released details on San Diego scandal, ESPN (May 22, 2013), https://www.espn.com/blog/collegebasketballnation/post//id/84846/fbi-releases-detailson-san-diego-scandal, accessed March 3, 2020.

120 S. 3793, 115th Congress, 2nd Session, https://www.congress.gov/bill/115th-congress/senate-bill/3793, 2018, Section 103(b)(15), p. 46.

${ }^{121}$ See Becky Harris, Regulated Sports Betting: A Nevada Perspective, 10 UNLV Gaming L.J. 75, 84-86 (2020).

${ }^{122} \mathrm{Id}$.
} 
- Arizona State players Stevin "Hedake" Smith and Isaac Burton fixed four games during the 1993-1994 season by colluding with illegal book makers. ${ }^{123}$ Las Vegas bookmakers helped uncover the scheme by alerting authorities to suspicious betting patterns after taking around $\$ 900,000$ in wagers on an Arizona State-Washington game, which would typically generate $\$ 40,000$ in wagers. ${ }^{124}$

- The Nevada Gaming Control Board worked with the NCAA when it requested information regarding the betting activity of a University of Florida basketball player who gave inside information on games to a bookmaker. ${ }^{125}$

- In the first major gambling case involving two sports on a college campus, Toledo Rockets football and basketball players conspired with gamblers to shave points in games from 2004 to 2006. Kenny White, who owned the Las Vegas Sports Consultants odds-making firm at the time, first alerted the NCAA to suspicions of point shaving at Toledo after noticing irregular betting patterns on its games. ${ }^{126}$

- In 2014, the FBI reached out to the Nevada Gaming Control Board about University of Texas El Paso basketball. Three players were kicked off the team for betting on games. A bookmaker unsuccessfully attempted to recruit the players to fix a game but did not get them to bet. ${ }^{127}$

The proposed legislation continues its mandates to state regulators in Section $103(\mathrm{~b})(15)(\mathrm{B})^{128}$ by requiring state regulatory agencies to "... cooperate with any lawful investigation" conducted by:

- federal or state law enforcement; or

${ }^{123}$ Arizona State University Point Shaving Scandal, History Collection, https://historycollection. co/10-confirmed-cases-gamblers-influencing-outcome-historical-sporting-events/5/, accessed April 1, 2020.

${ }^{124}$ Dewey, supra note 117 (there is no record that any inside knowledge of the fix was utilized when wagers were placed in Nevada).

${ }^{125}$ Staff \& Wire Reports, Dupay Allegedly Shared Gambling Winnings, L.A. Times (Sept. 15, 2001), https://www.latimes.com/archives/la-xpm-2001-sep-15-sp-46059-story.html (there is no record that any inside knowledge of the fix was utilized when wagers were placed in Nevada).

${ }^{126}$ Dewey, supra note 117 (there is no record that any inside knowledge of the fix was utilized when wagers were placed in Nevada).

127 Aaron Martinez, Bookie in UTEP Basketball Betting Scandal Pleads Guilty, El PAso Times (Oct. 21, 2016), https://www.elpasotimes.com/story/news/crime/2016/10/21/bookie-utep-bettingscandal-pleads-guilty/92487014/ (no significant bets were taken on the games with Nevada sports pools and race books. There is no record that any inside knowledge of the fix was utilized when wagers were placed in Nevada).

${ }^{128}$ S. 3793, 115th Congress, 2nd Session, https://www.congress.gov/bill/115th-congress/senate-bill/3793, 2018, Section 103(b)(15)(B), pp. 46-47. 
- a sport organization with respect to a sports wager

on a sporting event sponsored, organized or conducted by the sports organization; and

accepted by a sports wagering operator located or operating in the state.

Cooperation is a nebulous term and not one that is defined in SWMIA. Though it is anybody's guess as to what would constitute cooperation, cooperation would be difficult if the interests of the various parties required to cooperate in the investigation are in opposition.

Despite the strong relationships with professional sports leagues and collegiate athletic organizations that state regulators have cultivated, one of the challenges with mandating cooperation with a non-governmental entity is that state gaming regulatory agencies have statutory confidentiality requirements. ${ }^{129}$

In Nevada, "any communication or document of an applicant, licensee or club venue operator, or an affiliate of an applicant, licensee or club venue operator, which is made or transmitted to the Board or Commission or any of their agents or employees to: ... (c) Assist the Board or Commission in the performance of their respective duties, is absolutely privileged ..."130

Further, subsection 3 of NRS 463.3407 states, "(a) The Board, Commission and their agents and employees shall not release or disclose any information, documents or communications provided by ... [a] licensee ..., which are privileged pursuant to chapter 49 of NRS, without the prior written consent of the ... licensee ..."

To the extent cooperation would include the sharing of information, cooperation can become challenging and may be impossible if one party, such as a state regulatory entity, is subject to statutorily imposed confidentiality requirements. Cooperation could also become impossible if the parties required to cooperate disagree as to whether or not requested information is confidential. In the event confidential information is sought from state gaming regulators by private parties, such as sports leagues, complying with the request would be impossible as a matter of law. The very suggestion that Congress could require state gaming regulators to divulge privileged, confidential information to private third parties is unreasonable.

\section{Official League Data Requirements}

Prior to the Supreme Court repeal of PASPA, US sports leagues had already begun advocating government-mandated use of official league data. ${ }^{131}$ The idea that sports leagues should determine how sports data could be utilized first appeared in a lobbying document circulated by the NBA and Major League Baseball (MLB) in February 2018. ${ }^{132}$ That same month, Connecticut legislators

\footnotetext{
129 See NRS 463.120 and NRS 463.3407.

130 NRS 463.3407

131 Official League Data, LEgAL SPORTs REP. https://www.legalsportsreport.com/official-league-data/, (updated Feb. 14, 2020), accessed March 18, 2020.

132 Id.
} 
were the first to hear the "full pitch" by the sports leagues and Kansas was the first state to consider adopting a tiered approach to official data. ${ }^{133}$ By June, just a month after PASPA was repealed, Pennsylvania became the first state to be asked by sports leagues to require sports book operators to use official league data. ${ }^{134}$ In August, Senator Schumer included an official league data mandate in his proposal for a federal sports betting framework. ${ }^{135}$

In a written statement submitted to the House Judiciary Subcommittee on Crime, Terrorism, Homeland Security and Investigations, in September of 2018, Jocelyn Moore, Executive Vice President for Communications and Public Affairs for the National Football League (NFL), requested that Congress consider adding "a requirement that states with legalized sports betting use official league data." 136

US sports leagues generally are lobbying state legislatures to include "official data" requirements in sports wagering legislation ${ }^{137}$ and the NBA, MLB, and the Professional Golfers' Association (PGA) have been united in their desire to require legal betting markets to use their "official data."138

It is not surprising that in December SWMIA mandated that sports betting operators use data provided or licensed by sport organizations or their designated affiliates to determine the outcome of sports wagers through $2024 .{ }^{139}$

Regarding the use of "Authorized Data"140 SWMIA dictates the following:

"With respect to any sports wager accepted on or before December 31, 2024 , provide that a sports wagering operator shall determine the result of a sports wager only with data that is licensed and provided by

${ }_{133}$ Id.
${ }^{134}$ Id.
${ }^{135}$ Schumer proposal supra note 17.
${ }^{136}$ Harris supra note 120 at 92 . See also Brett Smiley, Here's What Happened at the House Judiciary Hearing on Sports Betting, SPORTs HANDLE (Sept. 27, 2018), https://sportshandle.com/ heres-what-happened-at-the-house-judiciary-hearing-on-sports-betting/ (The Hearing took place on September 27, 2018. Video of the Hearing and written statements from each of the witnesses is linked within the article); see also Mike Florio, NFL Wants Official Data Used for Gambling, Restrictions on Certain Types of Bets, NBC SPORTs (Sept. 26, 2018), https://profootballtalk.nbcsports. com/2018/09/26/nfl-wants-official-data-used-for-gambling-restrictions-on-certain-types-of-bets/ (the NFL wants "official data" used for gambling restrictions on certain types of bets).

${ }^{137}$ Dustin Gouker, New 'US Sports Integrity' Website Pushes Leagues' Vision on Sports Betting Data, Legal SPORTs ReP. (Apr. 10, 2018), https://www.legalsportsreport.com/19730/sports-betting-integrity-and-data-rights/; Joe Lemire, New U.S. Sports Betting Markets Have Started a Data War, SPortTechie (June 29, 2018), https://www.sporttechie.com/sports-betting-official-data-rightsmlb-nfl-nba-pga-nhl-ncaa/.

${ }_{138}$ Harris supra note 120 at 92. Gouker, supra note 136; Lemire, supra note 136.

139 S. 3793, 115th Congress, 2nd Session, https://www.congress.gov/bill/115th-congress/senate-bill/3793, 2018, Section 103(b)(1)(4), p. 28.

140 S. 3793, 115th Congress, 2nd Session, https://www.congress.gov/bill/115th-congress/senate-bill/3793, 2018, Section 103(b)(5), p. 28. 
- the applicable sport organization; or

- an entity expressly authorized by the applicable sport organization to provide such information." 141

Data requirements for the "post-transition period would be determined later by State regulatory entities." 142 Had SWMIA passed, sports book operators would already be required to rely on official league data. Once required to use and rely on official league data, it is likely that sportsbook operators would have little appetite to change data providers. After a federally imposed mandate for close to five years, it would be pointless for state regulatory bodies to establish new and different regulations for data sources. Additionally, the requirement in Section 102(e) that requires states to file a renewal application to operate sports betting every three years would serve as a significant deterrent. ${ }^{143}$

The American Gaming Association has advocated that data contracts should not be mandated by federal or state governments; rather, the agreements should be between sporting bodies and gaming companies. ${ }^{144}$ The majority of the US jurisdictions that operate legalized sports wagering, and particularly Nevada, have demonstrated that official league data is not a requirement for operating sports betting with integrity. “... the market has already proven that it can act on its own without requiring operators to purchase official data, a requirement that illegal books do not have."145

Government mandates requiring contracts between private parties interfere with the marketplace and are bad policy. Currently, there is nothing that prohibits gaming operators, sports book operators and/or sports leagues from entering into voluntary arrangements for data. Indeed, many do. MGM Resorts International (MGM) has been pre-emptive with sports leagues and has agreements with the NBA, ${ }^{146}$ National Hockey League (NHL) ${ }^{147}$ and $\mathrm{MLB}^{148}$ for access to their data.

\footnotetext{
${ }_{141}$ S. 3793, 115th Congress, 2nd Session, https://www.congress.gov/bill/115th-congress/senate-bill/3793, 2018, Section 103(b)(5)(A)(i), p. 28.

${ }_{142}$ S. 3793, 115th Congress, 2nd Session, https://www.congress.gov/bill/115th-congress/senate-bill/3793, 2018, Section 103(b)(1)(5)iii), pp. 28-29.

${ }^{143}$ S. 3793, 115th Congress, 2nd Session, https://www.congress.gov/bill/115th-congress/senate-bill/3793, 2018, Section 103(d), p. 19.

144 Press Release AGA Outlines Sports Betting Priorities in Letter to Congress, Ам. Gaming Ass'N, (May 22, 218), https://www.americangaming.org/newroom/press-releases/aga-outlines-sprots-betting-priorities-letter-congress.

${ }^{145}$ Steve Galloway \& Brendan Bussman, The Importance of Data in Sports Betting: Why the leagues are demanding "integrity fees" and how in-play" wagering will explode, GloBal Gaming Bus., 15 (Feb. 2019).

146 David Purdum \& Darren Rovell, NBA Signs Deal With MGM To Be Gaming Partner, ESPN (July 31, 2018), https://www.espn.com/chalk/story/_id/24245142/nba-first-league-betting-sponsordeal-mgm.

147 Dan Rosen, NHL, MGM Resorts Form Sports Betting Partnership, NHL News (Oct. 29, 2018), https://www.nhl.com/news/nhl-mgm-resorts-sports-betting-partnership/c-301392322.

${ }^{148} \mathrm{Id}$.
} 
Fox Bet has a "multi-year partnership with and is an Authorized Gaming Operator of MLB." 149 DraftKings and Fan Duel also boast official data partnerships with MLB. ${ }^{150}$ The XFL chose Sportradar as an exclusive media and sports data provider for its new league. ${ }^{151}$ And there are many others.

With a variety of gaming stakeholders entering into agreements for data, curiosity abounds as to what they are really buying. In terms of the NHL/MGM arrangement, MGM is entitled to "receive access to "previously unseen enhanced NHL proprietary game data." 152 Sportradar has promised to deliver a "wide range of pre-match and live betting services along with bet stimulation content such as live match trackers" through its partnership with MGM. ${ }^{153}$ MLB has made it clear the benefits of becoming an authorized gaming operator (AGO) partner include status as an official data licensee of the league, use of the MLB logo and "access to MLB club partnerships, media and content extension." 154

Among the various states that offer legalized sports wagering, only fourTennessee, ${ }^{155}$ Illinois, ${ }^{156}$ Michigan, ${ }^{157}$ and Virginia ${ }^{158}$-require the use of official

\footnotetext{
${ }_{149}$ Matt Rybaltoski, FOX Bet Becomes An MLB Authorized Gaming Operator Days Before World Series, Sports Hande (Oct 15, 2019), https://sportshandle.com/fox-bet-mlb-authorized-gaming-operator/, accessed March 10, 2020.

$150 \mathrm{Id}$.

151 Sportradar Signs XFL Official Sports Data Partnership, Gaming Intelligence (Feb. 13, 2020), https://www.gamingintelligence.com/products/fantasy-sports/89698-sportradar-signs-xfl-official-sports-data-partnership/, accessed March 10, 2020.

152 Todd Prince, MGM Resorts, NHL Sign Sports Betting Partnership Deal, L.V. REv. J. (Oct. 29, 2018), https://www.reviewjournal.com/business/casinos-gaming/mgm-resorts-nhl-sign-sportsbetting-partnership-deal/, accessed June 26, 2020.

${ }^{153}$ MGM GVC Interactive Announces Sportradar as an Exclusive Supplier of U.S. Sports Data, Bus. Wire (Nov. 8, 2018), https://www.businesswire.com/news/home/20181108005434/en/ MGM-GVC-Interactive-Announces-Sportradar-Exclusive-Supplier/.

154 Rybaltowski supra note 148.

155 Adam Candee, Allow Us to Volunteer: The Tennessee Sports Betting Bill is Really Bad, LEGAL SpORTs ReP. (May 9, 2019), https://www.legalsportsreport.com/32035/tennessee-sports-betting-official-data/, accessed March 25, 2020.
}

156 Brett Smiley, How 'Unofficial' Sports Betting Data May Be Better than 'Official League Data', Sports Hande (June 5, 2019), https://sportshandle.com/unofficial-official-league-data.

157 Beth LeBlanc, Ahead of sports betting bill, GOP lawmakers met league officials at PGA Tour headquarters, Detroit News (January 20, 2020), https://www.detroitnews.com/story/news/politics/2020/01/20/ahead-sports-betting-bill-michigan-lawmakers-met-pga-mlb-nba/4522528002/, accessed March 19, 2020.

158 Virginia's Governor signed the sports betting legislation on April 22, 2020, Virginia Sports betting - Where to Play, Online Sportsbooks And Bonus Offers, SPORTs HandLe, https://sportshandle.com/virginia/, accessed June 25, 2020; see also Matthew Waters, How Virginia Became Second State to Legalize Sports Betting in 2020, Legal Sports ReP. (updated May 12, 2020), https://www.legalsportsreport.com/40303/virginia-sports-betting-legalized-2020/, accessed June $25,2020$. 
league data. All four states require that official league data be provided upon "commercially reasonably terms," 159 though what that constitutes remains to be seen.

Tennessee, the first state to enact official league data requirements for live betting, provided no guidance on what is meant by commercially reasonable data, preferring instead to leave the mechanics up to the regulatory entity.

"A licensee shall exclusively use official league data for purposes of live betting unless the licensee can demonstrate to the board that the governing body of a sport or sports league, organization, or association or other authorized entity cannot provide a feed of official league data for live betting in accordance with commercially reasonable terms, as determined by the board." 160

Using the Tennessee language as the foundation for imposing a commercially reasonable requirement, Illinois was a little more nuanced in its approach and was the first to create a tiered system for official league data.

Tier 1 sports wagers are placed prior to the commencement of an event and the result is based on final outcome/score. ${ }^{161}$ Tier II sports wagers are wagers that are not considered to be Tier $1 .^{162}$ In-game wagers, in-play wagers, and proposition bets are considered to be Tier II.

Tennessee requires,

"Within 30 days of a sports governing body notifying the Board, master sports wagering licensees shall use only official league data to determine the results of tier 2 sports wagers on sports events sanctioned by that sports governing body, unless:

1. the sports governing body or designee cannot provide a feed of official league data to determine the results of a particular type of tier 2 sports wager, in which case master sports wagering licensees may use any data source for determining the results of the applicable tier 2 sports wager until such time as such data feed becomes available on commercially reasonable terms; or

2. a master sports wagering licensee can demonstrate to the Board that the sports governing body or its designee cannot provide a feed of official league data to the master sports wagering licensee on commercially reasonable terms. During the pendency of the Board's determination, such master sports wagering licensee may use any data source for determining the results of any and all tier 2 sports wagers."'163

\footnotetext{
159 Tenn. Code Ann. §4-51-316; § 230 ICLS 45/25-25(g); Michigan Complied Laws 432.410(a); and Virginia Enrolled House Bill 896 § 58.1-4036.

${ }_{160}$ Tenn. Code Ann. §4-51-316.

${ }^{161}$ Official League Data supra note 130.

${ }^{162} \mathrm{Id}$.

$163 \S 230$ ICLS $45 / 25-25(\mathrm{~g})$
} 
Michigan Enrolled House Bill 4619, Section 10(a)(3)(b), ${ }^{164}$ was the first legislative attempt to articulate factors to be considered in determining whether or not official league data could be obtained upon commercially reasonable terms.

"(b) A sports betting operator can demonstrate to the board that the sports governing body or its designee will not provide a feed of official league data to the sports betting operator on commercially reasonable terms.

The following is a nonexclusive list of other factors the board may consider in evaluating whether official league data is being offered on commercially reasonable terms:

(i) The availability of a sports governing body's tier 2 sports bet official league data to a sports betting operator from more than 1 authorized source.

(ii) Market information regarding the purchase by operators of data from any authorized source including sports governing bodies or their designees for the purpose of settling sports wagers, for use in this state or other jurisdictions.

The nature and quantity of data, including the quality and complexity of the process used for collecting the data.

The extent to which sports governing bodies or their designees have made data used to settle tier 2 sports bets available to operators."

During its 2020 legislative session, Virginia followed the Michigan model with two modifications. Instead of requiring regulators to consider the "extent to which sports governing bodies or their designees have made data used to settle tier 2 sports bets available to operators," Virginia legislators instead chose to provide its chief regulator with some discretion by allowing the regulators to consider "[a]ny other information the Director deems relevant." 165

Both the Michigan and Virginia legislation provide the requirement that sports governing bodies must be able to provide official league data to resolve tier 2 sports bets from more than one authorized source. While this provision will not ensure that there will be adequate competition in the marketplace for official league data, it does prevent sports leagues from utilizing only one data provider. ${ }^{166}$

While to date states disagree on the necessity of mandating official league data, there is unanimous agreement among stakeholders that the data used to settle wagers in sports betting must be accurate. As more states consider legalizing sports wagering, it will be interesting to see whether or not future legislation or state gaming regulations will include language on how market rates could be

\footnotetext{
164 State of Michigan, House Bill 4916, 100th Legislature, Regular Session, 2019, https://www. legislature.mi.gov/documents/2019-2020/publicact/pdf/2019-PA-0149.pdf.

165 Virginia Enrolled House Bill 896 § 58.1-4036.

166 A special thanks to Matt Rybaltowski for his invaluable insight and helpful conversations.
} 
calculated for official league data, thresholds that prevent data providers from charging exorbitant rates or safeguards to prevent surge pricing. ${ }^{167}$

With regard to data, it is interesting to note that SWMIA does not contain any references to "commercially reasonable terms" or a single requirement that sports leagues provide data under such terms. Notably, Section 103(b)(5) just requires the use of "authorized data" until 2024. ${ }^{168}$

Through the state legislative process, it has been demonstrated that to the extent there is a desire to require official league data there must be a balance between a sports league's desire to monetize the data and the ability of legal sports book operators to provide reasonably priced wagers that incentivize bettors to move away from the illegal market.

One sports league representative has indicated that "regulators could ensure that league data is priced at "commercially reasonable terms." 169 Refusing to discuss the matter in an "open hearing," she "declined to give even a rough idea of what those prices are." Whether or not state legislatures will decide to require official league data to resolve wagers, they have demonstrated that they are more than capable of establishing their regulatory priorities.

At present, data intermediaries with the ability to provide official league data to sports books are incredibly few in number. Sportradar and Genius Sports already have exclusive agreements with several of the sports leagues while Scientific Games, Don Best Sports, and Perform Group provide data to sports books. ${ }^{170}$ According to Matthew Holt, President of U.S. Integrity, ${ }^{171}$ the number of companies that provide official league data are so limited as to potentially create a monopoly. He cautions states to "avoid passing legislation mandating the use of official sports league betting data when the packages are distributed by a select few. Not only could it represent the worst-case scenario for the industry, it is irresponsible from a regulatory standpoint." 172 He further reasons, "If you want to mandate to league data, it just doesn't seem fair to create any monopolies."'173

\footnotetext{
${ }^{167}$ Matt Rybaltowski, Shakedown Fees: NBA, MLB Demanding Nevada Sportsbooks Pay More Or Get Cut Off, Sports Handle (May 2, 2019), https://sportshandle.com/nba-mlb-demands-data-feenv-sportsbooks/, accessed April 1, 2020.
}

168 S. 3793, 115th Congress, 2nd Session, https://www.congress.gov/bill/115th-congress/senate-bill/3793, 2018, Section 103(b)(5), p. 28.

${ }^{169}$ Andy Metzger, Betting notes: DeLeo want floor vote on sports bill, Commonwealth Mag. (May 29, 2019), https://commonwealthmagazine.org/politics/betting-notes-deleo-wants-floor-vote-onsports-bill/, accessed April 1, 2020.

${ }^{170}$ Matt Rybaltowski, Here's How Much 'Official' League Data Actually Costs, Sports HandLE (Mar. 12, 2019), https://sportshandle.com/sports-betting-official-data-cost/, accessed March 10, 2020 .

${ }^{171}$ US Integrity provides game integrity, fraud prevention and awareness programs for US sports betting. US Integrity works with regulated sports book operators and professional and collegiate sports leagues.

172 Rybaltowski, supra note 169.

${ }^{173}$ Id. See also Darren Rovell, Senate Minority Leader Chuck Schumer suggests federal framework for sports betting, ESPN (Aug. 29, 2018), https://www.espn.com/chalk/story//id/24511871/ chuck-schumer-suggests-federal-framework-sports-betting, accessed March 2, 2020. 
In its Finding. 8. in the preamble to the bill, Congress signaled that some of the legislative intent behind the bill included, "... incentivizing participants in the illegal sports wagering market to shift their activity into the legal sports wagering market ..."174 If this is, in fact, part of the purpose of the legislation, then mandating official league data only serves to encourage the illegal market by increasing the cost of legal wagers and creating additional barriers with which legal sports book operators will have to comply.

Illegal and unlicensed bookmakers would have benefitted from the SWMIA legislation because they don't worry about utilizing official league data, forming league partnerships or paying compensation for the use of league IP and trademarks. Nor do illegal bookmakers "worry about complying with regulations, paying taxes, or establishing reserve accounts. While some illegal operators may pay fees, perhaps pay taxes, and may even follow some regulations, what we know for sure is that many illegal operators serve their customers with sophisticated and attractive websites, provide a seamless transaction experience, and make betting easy for their customers. Illegal bookmakers do not have the same regulatory infrastructure costs, can offer more betting options, are more convenient, providing payment plans [for customer losses], and extend credit. This is all done without regulatory oversight, patron dispute processes, protection of patron funds, or responsible gambling messaging." 175

Rather than incentivizing the legal sports wagering market, Congress would have fostered the very conditions necessary for the illegal market to thrive. As legal sports books navigate complex regulatory structures and bear the costs associated with that regulation, illegal bookies and/or gambling operators become more attractive to potential bettors because they can offer less expensive betting options. By adding yet another layer of regulation, Congress would have failed to achieve its objective and SWMIA would have only added to the regulatory burdens legal sports book operators already face by increasing the cost of providing legal sports wagering products.

\section{National Clearinghouse for Sports Wagering Data}

Section 106 of SWMIA is dedicated to establishing a National Sports Wagering Clearinghouse. According to Section 106(a), the National Wagering Clearinghouse shall be a nonprofit organization that not owned by any other entity; ${ }^{176}$ and among

\footnotetext{
174 S. 3793, 115th Congress, 2nd Session, https://www.congress.gov/bill/115th-congress/senate-bill/3793, 2018, Finding (8), pp. 4-5.

175 Harris, supra note 120 at 94. A special thanks to Chief Karl Bennison (retired) of the Nevada Gaming Control Board for his experience, review, and editing of this paragraph.

See also U.S. v. DiCristina, 886 F. Supp. 2nd 164, 207, 209 (2012). See also David Purdum, One year into legal U.S. sports betting: What have we learned?, ESPN (May 13, 2019), https://www. espn.com/chalk/story/_id/26740441/one-year-legal-us-sports-betting-learned, accessed March 25, 2020 .

176 S. 3793, 115th Congress, 2nd Session, https://www.congress.gov/bill/115th-congress/senate-bill/3793, 2018, Section 106(a), pp. 52-53.
} 
other things is established for the purpose of "operat[ing] the official national resource center and information clearinghouse for sports wagering integrity."177

Federal creation of a non-profit entity to engage in integrity monitoring is unnecessary, particularly because The Sports Wagering Integrity Monitoring Association (SWIMA), a nonprofit organization, was established in November 2018, the month before the federal legislation was proposed. SWIMA is "... designed to detect and discourage fraud and other illegal or unethical activity related to betting on sports in the United States." 178

Though participation is voluntary, SWIMA is a collective, where member sports book operators throughout the US, both state and tribal, can share data to identify suspicious wagering activity. ${ }^{179}$ SWIMA is also dedicated to working with state, federal, and tribal law enforcement as well as other stakeholders. ${ }^{180}$

There are several reasons SWIMA is a better alternative than the proposed federal regulation. First, is was not the result of a government mandate. Though a voluntary association, there are currently 29 members. ${ }^{181}$ Second, it is an organization that can exist in perpetuity, whereas Congress contemplated the potential for the National Clearinghouse to change hands every five years if necessary. ${ }^{182}$ The inclusion of this provision in the federal legislation makes it seem as if Congress did not expect the administration of the National Clearinghouse to be effective. Failing to set something as significant as a National Clearinghouse for sports wagering integrity up for success would be disruptive, inefficient, inject uncertainty into the industry and continue to foster an illegal market for sports wagering.

Third, Congress never intended to fund the National Clearinghouse. Though some initial federal funding was contemplated for the first three fiscal years of the federal regulatory rollout, the statutory formula makes the grant the lesser of $\$ 3$ million or the amount of the federal sports betting excise tax collected in the preceding fiscal year. ${ }^{183}$ In 2019 , Nevada alone had a sports betting handle of $\$ 5.3$ billion. ${ }^{184}$ When the $0.25 \%$ formula is applied, Nevada operators paid $\$ 13.25$

\footnotetext{
177 S. 3793, 115th Congress, 2nd Session, https://www.congress.gov/bill/115th-congress/senate-bill/3793, 2018, Section 106(c)(1), p. 56.

178 Hilary Russ, First sports betting integrity group launched in United States, ReUTERs (Nov. 27, 2018), https://uk.reuters.com/article/usa-gambling-sports/first-sports-betting-integrity-grouplaunched-in-united-states-idUKL2N1Y21I6, accessed March 20, 2020; About SWIMA, SWIMA https://www.swima.net/, accessed February 29, 2020.

179 SWIMA, supra note 177.

${ }^{180}$ Russ, supra note 177.

181 SWIMA, supra note 177.

182 S. 3793, 115th Congress, 2nd Session, https://www.congress.gov/bill/115th-congress/senate-bill/3793, 2018, Section 106(b)(1)(A) \& (B) and 106(b)(2)(A), pp. 54-55.

183 S. 3793, 115th Congress, 2nd Session, https://www.congress.gov/bill/115th-congress/senate-bill/3793, 2018, Section 106(g), p. 63. Though the statutory formula makes the grant the lesser of $\$ 3$ million or the amount of the federal sports betting excise tax collected in the preceding fiscal year, in 2019 Nevada collected $\$ 5.3$ billion in sports betting handle.

${ }_{184}$ Brian Pempus, Nevada Sports Betting Handle Soars to \$5.3B in 2019, US Bets (Jan. 30, 2020), https://www.usbets.com/nevada-2019-sports-betting-record/, accessed March 20, 2020.
} 
million to the federal government for its share of the excise tax, well over the $\$ 3$ million funding ceiling established in the proposed legislation.

Though the bill sponsors seem to like the idea of trying to establish measures that might improve sports integrity, they were not committed enough to it to have the federal government actually fund those efforts. Further indications that Congress wasn't serious about funding sports integrity efforts is found in the next paragraph titled "Sense of Congress." ${ }^{185}$ In Section A, it is articulated that "any funds appropriated to carry out this section shall not be the sole or primary funding to operate the National Sports Wagering Clearinghouse."'186

To add insult to injury, it appears that the funding mechanism of the bill was to push the costs onto "... sports wagering operators, sports organizations and State regulatory entities through voluntary contributions by or reasonable fees assessed ..."187 State regulatory agencies with their limited budgets have no extra money to contribute to a federally established nonprofit entity. Moreover, state agencies are dependent upon state legislatures to fund their budgets. With most states looking to legalize sports betting to bolster their budgets, ${ }^{188}$ requests for funding to assist the federal government's efforts would likely fall on deaf ears. Had the federal legislation been enacted and then litigated, Section 106(g) (B) could have proven to be problematic and possibly unconstitutional as applied to the states. In Murphy v. National College Athletic Association, the Supreme Court reasoned

the anticommandeering principle prevents Congress from shifting the costs of regulation to the States. If Congress enacts a law and requires enforcement by the Executive Branch, it must appropriate the funds needed to administer the program. It is pressured to weigh the expected benefits of the program against its costs. ${ }^{189}$

\footnotetext{
185 S. 3793, 115th Congress, 2nd Session, https://www.congress.gov/bill/115th-congress/senate-bill/3793, 2018, Section 106(g)(2), p. 63.

186 S. 3793, 115th Congress, 2nd Session, https://www.congress.gov/bill/115th-congress/senate-bill/3793, 2018, Section 106(g)(A), p. 63.

187 S. 3793, 115th Congress, 2nd Session, https://www.congress.gov/bill/115th-congress/senate-bill/3793, 2018, Section 106(g)(B), pp. 63-64.

188 Ulrick Boesen, Sports Betting Might Come to a State Near You, TAx Foundation (Mar. 3, 2020), https://taxfoundation.org/legal-sports-betting-states/, accessed March 20, 2020; Joseph P. Addabbo, Jr, Facing massive budget shortfall in 2020, Addabbo believes mobile sports betting could help bridge that gap, N.Y. SENATE (Jan. 23, 2020), https://www.nysenate.gov/newsroom/ press-releases/joseph-p-addabbo-jr/facing-massive-budget-shortfall-2020-addabbo-believes, accessed March 2020; States might turn to legalized gambling with budgets rocked by coronavirus, Associated Press (May 29, 2020) https://nypost.com/2020/05/29/states-might-turn-to-legalized-gambling-with-budgets-rocked-by-coronavirus/, accessed July 7, 2020.

189 Murphy v. National Collegiate Athletic Association, 584 U.S.__, 138 S. Ct. 1461 (2018) (at 18 slip opinion).
} 


\section{How Federal Legislation Might be Effective}

\section{A. Interstate Sports Wagering Compacts}

Section 105 of SWMIA permits states to enter into interstate wagering compacts "to offer sports wagering ... between (A) 2 or more States with a State sports wagering program; (B) 1 or more States with a State sports wagering program and 1 or more Indian Tribes; or (C) 2 or more Indian Tribes," ${ }^{190}$ if the U.S. Attorney General authorizes the agreement. ${ }^{191}$

Interstate sports wagering compacts, if done correctly, can provide a lot of liquidity, fill gaps in the market, and promote good will among the tribal jurisdictions and states. Tribal participation is especially important because New Mexico's tribal compact for gaming appears to "authorize 'any and all forms of Class III' on Indian lands within the state"192 and has been operating sports books since October 16, 2018. ${ }^{193}$ On March 25, 2020, Washington State became the first state to offer tribal-only sports wagering. ${ }^{194}$ Washington's tribal sports wagering lacks a mobile component and is limited to brick and mortar casinos. ${ }^{195}$

On February 26, 2014, the governors of Nevada and Delaware signed the first-ever liquidity sharing agreement. The Multi-State Internet Gambling Association (MSIGA). "Generally speaking, each state will receive the percentage of the rake from each poker hand that's attributable to players from that state," said Governor Markell. "Players from Delaware will be subject to the Delaware laws and regulations, and players from Nevada will be subject to Nevada's laws

\footnotetext{
190 S. 3793, 115th Congress, 2nd Session, https://www.congress.gov/bill/115th-congress/senate-bill/3793, 2018, Section 3. Definitions (9), p. 8.

191 S. 3793, 115th Congress, 2nd Session, https://www.congress.gov/bill/115th-congress/senate-bill/3793, 2018,
}

Sections 105(b) \& 105(b)(3), pp. 50-51.

192 New Mexico Sports Betting, The Lines (updated Jan. 16, 2020), https://www.thelines.com/nm/, accessed March 26, 2020.

193 Id.

194 Tom Banse, Sports Betting Now Legal in Washington, But Limited to Tribal Casinos, OPB (Mar. 26, 2020), https://www.opb.org/news/article/washington-state-sports-betting-legal-trbial-casinos/, accessed March 26, 2020.

195 Jill R. Dorson, It's Official: Washington Governor Signs Sports Betting Bill, SPORTs HaNDLE (Mar. 25, 2020), https://sportshandle.com/its-official-washington-sports-betting-governor/, accessed April 15, 2020. Because the State of Washington limited sports betting to brick and mortar casinos, Washington has avoided having to consider whether or not tribal mobile sports wagering would run afoul of UIGEA. See California v. Iipay Nation of Santa Ysabel, 898 F. 3d 960 (9th Cir. 2018). 
and regulations." ${ }^{196}$ New Jersey signed the agreement a few years later ${ }^{197}$ and by the time the online website was live on April 30, 2018, ${ }^{198}$ all three states were participants.

MSIGA has demonstrated that interstate compacts are possible, and Delaware, Nevada, and New Jersey have already proven that interstate agreements are successful. States should come to expect the ability to enter into similar agreements for sports betting.

One benefit of interstate compacts is that they can be tailored to meet the needs of a particular jurisdiction. For example, though three states have signed MSIGA, they are allowed to participate in the agreement in different ways. MSIGA provides a vehicle to increase poker liquidity so that gamblers from different states can participate in an online format and not be frustrated. In addition to participating in poker, Delaware and New Jersey share in online casino offerings. New Jersey in particular has invested heavily in its online casino offerings. ${ }^{199}$ Despite the casino closures that occurred as part of the US response to the COVID-19 outbreak, ${ }^{200}$ New Jersey was able to continue its online casino offerings and continue to generate state revenue while adhering to social distancing protocols. $^{201}$

${ }^{196}$ Marco Valerio, Nevada and Delaware sign liquidity sharing agreement under new Multi-State Gaming Association, IGAming Bus. (Feb. 24, 2014), https://www.igamingbusiness.com/news/ nevada-and-delaware-sign-liquidity-sharing-agreement-under-new-multi-state-internet-gaming, accessed February 29, 2020.

197 Thomas Moore, Pact allows New Jersey player on Nevada online poker sites, L.V. Sun (updated Oct. 13, 2017), https://lasvegassun.com/news/2017/oct/13/pact-lets-new-jerseyans-gamble-online-in-nevada-de/, accessed February 29, 2020.

${ }^{198}$ Martin Derbyshire, Christmas Came Early For NV, NJ, And DE Online Poker Players, PLAY USA (May 1, 2018), https://www.playusa.com/wsop-online-pooling-launches/, accessed February 29, 2020.

199 Roger Gros, Cause \& Effect: Will the legalization of sports betting spur states to also legalize iGaming?, Global Gaming Bus., 39 (Feb. 2019).

${ }^{200}$ Rachel Siegel, All bets are off: Casinos grind to a halt over coronavirus, WASH. Post (Mar. 16, 2020), https://www.washingtonpost.com/business/2020/03/15/casinos-coronavirus-closures-jobs/, accessed March 20, 2020; Anita Hassan, An 'unprecedented' shutdown, NBC News (March 23, 2020), https://www.nbcnews.com/news/us-news/las-vegas-neon-lights-go-dark-coronavirus-outbreak-leaves-thousands-n1167181, accessed July 1, 2020; Dawn Stover, Spirit Mountain, other tribal casinos take huge hit from coronavirus closures, OrEgOn Live/ THE OREgonian, (updated Apr. 20, 2020), https://www.oregonlive.com/business/2020/04/spirit-mountain-other-tribal-casinos-take-huge-hit-from-coronavirus-closures.html, accessed July 1, 2020; Katie Kohler, Pennsylvania Casinos React to Coronavirus: Live Updates on PA Closures, Play Pennsylvania (updated Mar. 19, 2020), https://www.playpennsylvania.com/pa-casino-closures-updates/, accessed March 20, 2020; David Purdum, 100\% of U.S. casinos to be closed by Wednesday, ESPN (Mar. 24, 2020), https://www.espn.com/chalk/story/_id/28947622/100-us-casinos-closed-wednesday, accessed March 26, 2020.

${ }^{201}$ Neil Bisman, NJ online casino gambling as option as physical casinos in New Jersey close, NJ.com (Mar. 19, 2020), https://www.nj.com/betting/casino/nj-online-casino-gambling-an-optionas-physical-casinos-in-new-jersey-close.html, accessed March 20, 2020. 
In 2017, Pennsylvania became the fourth state to legalize online poker and allow for Pennsylvania to enter into interstate liquidity agreements. ${ }^{202}$ It is still unclear whether or not Pennsylvania will choose to join MSIGA or what a potential timeline might look like.

Though it has only operated for about two years, MISGA certainly shows that allowing for states to enter into gaming compacts does not prevent them from adhering to their regulatory mandates to keep gambling free from criminal elements. Nor does entering into shared liquidity pools result in reduced levels of enforcement.

As states legalize sports betting, there appears to be a growing trend to authorize online casino gaming as companion legislation. Perhaps other states such as West Virginia ${ }^{203}$ and Michigan ${ }^{204}$ will find value in joining MISGA. ${ }^{205}$

While changes to the Federal Wire Act of 1961 would have to be made, Section 301 of SWMIA clarifies amendments to the Wire Act to allow interstate sports wagering transactions to take place across state lines. ${ }^{206}$

\footnotetext{
${ }^{202}$ Multi-State Legal Online Poker, OnLine PoKer Rep. (updated January 6, 2020), https://www. onlinepokerreport.com/multi-state-poker/, accessed February 29, 2020.

${ }^{203}$ Online Gambling and Poker Tracker, OnLIne PoKer ReP. (updated June 22, 2020), https://www.
} onlinepokerreport.com/bill-tracker/, accessed June 26, 2020.

${ }^{204}$ Michigan Online Gambling, OnLine PoKer ReP. https://www.onlinepokerreport.com/us/mi/, accessed February 29, 2020.

${ }^{205}$ Gros, supra note 198. West Virginia and Michigan both currently have legislation that allows for online gaming.

${ }^{206}$ S. 3793, 115th Congress, 2nd Session, https://www.congress.gov/bill/115th-congress/senate-bill/3793, 2018, Sections 301, pp. 68-88. On September 20, 2011, the Assistant Attorney General, Criminal Division for the US Department of Justice authored a formal legal opinion regarding the Wire Act of 1961 that concluded, "interstate transmissions of wire communications that do not relate to a 'sporting event or contest' ... fall outside the reach of the Wire Act." Virginia A. Seitz, Assistant Attorney General, Criminal Division, Department of Justice, Whether Proposals By Illinois and New York to Use the Internet and Out-Of-State Transaction Processors to Sell Lottery Tickets to In-State Adults Violate the Wire Act at 1 (Sept. 20, 2011), available at https:// www.justice.gov/sites/default/files/olc/opinions/2011/09/31/state-lotteries-opinion.pdf, accessed April 15, 2020. In an updated opinion, dated November 2, 2018, the Department of Justice, Office of Legal Counsel (OLC) reversed its opinion from 2011 and stated that the Wire Act's is "not uniformly limited to gambling on sporting events or contests." Steven A. Engel, Assistant Attorney General, OLC, at 23 (Nov. 2, 2018), available at https://www.justice.gov/olc/file/1121531/download, accessed April 15, 2020. On January 15, 2020, Rod Rosenstein for the Department of Justice announced it would suspend the enforcement of the Wire Act against "non-sports gambling" activities for 90 days. U.S. Department of Justice, Applicability of the Wire Act, 18 U.S.C. § 1084, to Non-Sports Gambling at 1 (Jan. 15, 2019), available at https://www.justice.gov/file/1124286/ download, accessed April 15, 2020. On February 15, 2019, the New Hampshire Lottery Commission filed a complaint asking the U.S. District Court For New Hampshire to vacate and set aside the 2018 Opinion. See New Hampshire Lottery Commission v. William Barr, United States District Court for the District of New Hampshire, Case 1:19-cv-00163 at 4, accessed April 15, 2020. On June 3, 2019, U.S. District Court Judge Paul Barbadoro granted the New Hampshire lottery's request for summary judgment when the court determined that the Wire Act is limited to sports gambling and set aside the 2018 OLC opinion. The Department of Justice filed notice of intent to appeal with the U.S. First Circuit Court of Appeals on August 16, 2019. See Dustin Gouker, US 


\section{B. Repurpose the Federal Excise Tax to Law Enforcement Efforts}

The federal excise tax imposed on sports wagering handle was established in 1951 and though the amount has changed over the years, it has remained at $0.25 \%$ since $1982 .^{207}$

In Section 2. Findings. (6), of SWMIA, Congress indicated that the illegal sports betting market is "much larger" than the legal sports market and "circumvents the taxation, anti-money laundering controls, and other regulations of the legal sports wagering market."208

In Section 2. Findings (7), Congress has declared that the "estimated size of the illegal sports wagering market suggests that the laws and enforcement efforts that for decades have sought to curtail illegal sports wagering have come up short."209

In Section 2. Findings (8), Congress has determined that state adoption of legal sports wagering regimes "presents an opportunity to significantly reduce the illegal sports wagering market by pairing enhanced authority for law enforcement to shut down the illegal sports wagering market with policies that incentivize participants in the illegal sports wagering market to shift their activity into the legal sports wagering market... so that such activity can be appropriately regulated and taxed." 210 While there is merit to these findings, SWMIA as currently constituted is not an effective solution.

In 2017, before other states were able to legalize sports wagering in their jurisdictions, Congresswoman Dina Titus (NV-I) sent a letter to the Internal Revenue Service (IRS) calling for an end to the handle tax, because offshore, black-market sportsbooks were not paying the tax, the IRS does not track the tax, the appropriation of funds is suspect, and while the $\$ 10$ million collected through the federal excise tax is insignificant to the federal government, it is a valuable sum for Nevada. ${ }^{211}$ Congresswoman Titus renewed her efforts to repeal the federal sports betting excise tax on July 24, 2020, by co-sponsoring new legislation with Congressman Guy Reschenthaler (PA-14). ${ }^{212}$

Online Gambling Still Under Threat: DOJ Is Appealing Its Loss In The Wire Act Case, OnLINE PoKer ReP. (Aug. 16, 2019), https://www.onlinepokerreport.com/38563/wire-act-case-appeal/, accessed July 3, 2020.

207 Eric Ramsey, Nevada Congresswoman Calls For End to Federal Sports Betting Handle Tax, Legal Sports ReP. (Dec. 13, 2017), https://www.legalsportsreport.com/16955/federal-sports-bet-

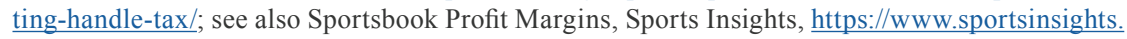
com/betting-tools/sportsbook-profit-margins/, accessed Dec. 3, 2019.

208 S. 3793, 115th Congress, 2nd Session, https://www.congress.gov/bill/115th-congress/senate-bill/3793, 2018, Finding (6), p. 4.

209 S. 3793, 115th Congress, 2nd Session, https://www.congress.gov/bill/115th-congress/senate-bill/3793, 2018, Finding (7), p. 4.

210 S. 3793, 115th Congress, 2nd Session, https://www.congress.gov/bill/115th-congress/senate-bill/3793, 2018, Finding (8), pp. 4-5.

211 Ramsey, supra note 206.

${ }^{212}$ Howard Stutz, Bipartisan Bill Introduced to End Federal Sports Betting Excise Tax, CDC GAMing RePORTs (July 24, 2020), https://www.cdcgamingreports.com/bipartisan-bill-introduced-to-end-federal-sports-betting-excise-tax/, accessed August 19, 2020. 
In 2018, when SWMIA was proposed, the \$10 million in taxes collected from Nevada looked to be augmented as other states came online with their legal sports betting programs. In the proposed legislation, Title II, Section 9511 created a "Wagering Trust Fund" for a variety of sports betting matters and allowed for assets in the fund to be used "for the investigation and prosecution of violations of ... the Sports Wagering Integrity Act of 2018, bribery ... illegal transmission of wagering information ... and any other crime which is committed incident to or is part of a scheme involving any crime or violation described in the preceding clauses."213

Combatting illegal activity, whether off-shore or within the US, will be an on-going reality. Cooperation between state and federal enforcement efforts is critical. Continued enforcement of the law is essential. Of necessity, regulators will have to create and then engage in new enforcement strategies in order to effectively combat illegal operators. In 1970 when the Illegal Gambling Business Act $^{214}$ was being considered in the Senate, Senator Gordon Allott (CO) stated, "[t]he Federal Government will not preempt the field of gambling regulation under this legislation. Federal authorities will continue in their traditional role of cooperating with local law enforcement officials who will continue to bear the primary responsibility in this area. The purpose of the statute is simply to make the Federal Government a more effective member of the established State-Federal law enforcement partnership which has long been waging a common war on organized crime and illegal gambling." 215 In this same spirit, with states continuing to set sports betting policy within their jurisdictions and the unique resources the federal government possess in terms of funding and police power, a combined effort would help tamp down the illegal sports betting operations that continue to persist.

Section 107 of SWMIA provides for the coordination of law enforcement agencies, though it is limited to federal agencies. ${ }^{216}$ Creating taskforces, developing interstate agreements, and/or facilitating departmental coordination between federal, state, and tribal gaming regulatory entities and their enforcement divisions would be an effective approach to combatting illegal sports betting enterprises. As jurisdictions work together to identify, prosecute and disassemble illegal gambling operations they could leverage knowledge and resources for better outcomes. A key component for the success for these types of shared agreements would be to ensure that appropriate resources are dedicated to enforcement efforts. Perhaps in this circumstance, more than any other, federal involvement could be effective.

\footnotetext{
213 S. 3793, 115th Congress, 2nd Session, https://www.congress.gov/bill/115th-congress/senate-bill/3793, 2018, Title II, Section 9511, pp. 65-67.

21418 U.S.C. $§ 1955$ (2018).

215116 Cong. Rec. 604, (Jan. 21, 1970).

216 S. 3793, 115th Congress, 2nd Session, https://www.congress.gov/bill/115th-congress/senate-bill/3793, 2018, Section 107, p. 64.
} 


\section{Conclusion}

Since the repeal of PASPA, states and tribal jurisdictions have demonstrated that they are able to implement robust regulatory schemes and efficiently and effectively regulate sports betting. A comprehensive federal system of regulation for sports betting is unwarranted and ill-advised. A federal sports betting regulatory regime would be disruptive, create additional barriers, add unnecessary complication, result in needless delays, increase the cost of legalized sports wagering products, and inject uncertainty into the industry. Additionally, the federal government has no experience or proficiency in regulating gaming. It would be a travesty to require state regulatory bodies to languish while waiting for regulatory approval and policy cues from the federal government.

The concepts contained within SWMIA are largely redundant because they are already part of the regulatory structures of the states and tribal jurisdictions that have legalized and now offer live sports betting. Rather than mandating the use of official league data that unnecessarily interferes with the commercial marketplace and hasn't been shown to increase the integrity of wagering, states should be allowed to pursue the public policy goals that are best for their jurisdictions. While not every jurisdiction has found it necessary to adopt official league data requirements, those states that find value in official league data can implement requirements that are specific to their purposes.

Integrity efforts to bridge the gap between gaming jurisdictions and sharing information have already been established and there is no need for federal duplication. Not interfering with state legislative and regulatory efforts as they craft their own regulatory policies will be the best way to combat illegal operators. Waiting for federal direction and the complications a new layer of bureaucracy brings would only foster the illegal market.

Federal efforts regarding gaming should be aimed toward reforming the Wire Act and providing dedicated funding for multi-jurisdictional enforcement efforts. Congress is best suited to pave the way for states to enter into interstate sports betting compacts. Nevada, New Jersey, and Delaware have demonstrated that interstate gambling compacts are achievable, have adhered to robust regulatory requirements, and are effective. Combating illegal activity is and will be an on-going reality for US gaming jurisdictions. Good relationships and coordinated efforts between state and federal law enforcement activities are critical. As jurisdictions work together, enforcement capabilities can be magnified, particularly if knowledge and resources are combined. 